\title{
Relationship between Electrochemical Parameters, Cytotoxicity Data against Cancer Cells of 3-Thio-Substituted Nor-Beta-Lapachone Derivatives. Implications for Cancer Therapy
}

\author{
Yen G. de Paiva, ${ }^{a, b}$ Thaissa L. Silva, ${ }^{a, c}$ André F. A. Xavier, ${ }^{a}$ Mariana F. C. Cardoso, ${ }^{d}$ \\ Fernando C. da Silva, ${ }^{\circledR d}$ Maria F. S. Silva, ${ }^{e}$ Daniel P. Pinheiro, ${ }^{\circledR e}$ Claudia Pessoa, ${ }^{e, f}$ \\ Vitor F. Ferreira ${ }^{g}$ and Marilia O. F. Goulart ${ }^{\circledR * a}$ \\ anstituto de Química e Biotecnologia, Universidade Federal de Alagoas, 57072-970 Maceió-AL, Brazil \\ ${ }^{b}$ Departamento de Sistemática e Ecologia (DSE), Centro de Ciências Exatas e da Natureza (CCEN), \\ Universidade Federal da Paraíba, Cidade Universitária, s/n, Castelo Branco III, \\ 58051-085 João Pessoa-PB, Brazil \\ ${ }^{c}$ Núcleo de Ciências Exatas (NCEx), Universidade Federal de Alagoas, Campus de Arapiraca, \\ 57309-005 Arapiraca-AL, Brazil \\ ${ }^{d}$ Departamento de Química Orgânica, Instituto de Química, Universidade Federal Fluminense, \\ Campus do Valonguinho, 24020-150 Niterói-RJ, Brazil \\ ${ }^{e}$ Laboratório de Oncologia Experimental, Departamento de Fisiologia e Farmacologia, \\ Universidade Federal do Ceará, 60430-275 Fortaleza-CE, Brazil \\ ${ }^{f}$ Fundação Oswaldo Cruz (Fiocruz) Ceará, 60175-047 Fortaleza-CE, Brazil \\ ${ }^{g}$ Departamento de Tecnologia Farmacêutica, Faculdade de Farmácia, \\ Universidade Federal Fluminense, 24241-002 Niterói-RJ, Brazil
}

\begin{abstract}
Electrochemical methods are powerful in the characterization and design of redox-modulating agents. We, herein, report the electrochemical investigation, in aprotic medium, of eleven synthetic 3-thio-substituted-nor-beta-lapachones, along with the determination of cytotoxic activity and correspondent selectivity index, against several cancer cell lines and one normal cell. Four of the quinones are novel compounds. The redox behavior is representative of two independent systems: the easy reduction of the quinone moiety and, at far more negative potential, the reductive cleavage of the $\mathrm{C}-\mathrm{S}-\mathrm{C}$ bonding; and the anodic part controlled by the oxidation of the sulfur moiety. The compounds have shown relevant cytotoxic activity, with emphasis on 3-phenyl-thio-2,2-dimethyl2,3-dihydronaphtho[1,2-b]furan-4,5-dione (compound 2), which mechanism of molecular action was shown to be related to reactive oxygen species (ROS) release. Despite the absence of a linear correlation, there is a trend: the majority of the thionaphthoquinones, with values of first wave reduction potential, less negative than $-0.65 \mathrm{~V}$, were active. The less electrophilic compound (3-(cyclohexylthio)-2,2-dimethyl-2,3-dihydronaphtho[1,2-b]furan-4,5-dione, cyclohexyl derivative) is also the less cytotoxic toward cancer cells. Agents containing chalcogens and quinones can be used to attack entities with a disturbed redox balance.
\end{abstract}

Keywords: thionaphthoquinones, electrochemical parameters, cancer, electrodic mechanism, ROS release, structure-electroactivity-biological activity relationship

\section{Introduction}

Redox processes, central to life, pervade practically all fundamental bioprocesses, from bioenergetics to metabolism and life functions. ${ }^{1}$

*e-mail: mariliaofg@gmail.com
A disturbed intracellular redox balance, resulting in oxidative stress (OS), has been considered as the biochemical basis for various human diseases, including different types of cancer. ${ }^{2,3}$ OS is an imbalance between oxidants, mainly reactive oxygen species (ROS), and antioxidants, in favor of the oxidants, leading to a disruption of redox signaling and control and/or molecular damage. ${ }^{1,2}$ 
Some cancer cells proliferate under conditions of high-intensity OS, ${ }^{1}$ compared with normal cells, because of their accelerated metabolism. ROS may cause damage to biological macromolecules, such as DNA, lipids and proteins, with noxious consequences to cells. Compared to non-cancerous cells, ROS levels are considerably closer to the critical redox threshold at which cell death is induced. ${ }^{4-6}$ Normal cells often can tolerate a certain level of exogenous ROS, whereas cancer cells cannot. ${ }^{7}$ These pre-existing biochemical differences between healthy and malignant tissues are significant and are used in the design of selective redox chemotherapeutic drugs. ${ }^{6-11}$

Some anticancer redox drugs have the ability to alter cellular redox status, by redox cycling-mechanism related to the reversible single electron transfer from a cellular reducing agent (e.g., glutathione or nicotinamide adenine dinucleotide phosphate $(\mathrm{NAD}(\mathrm{P}) \mathrm{H}))$ or other chemicals onto oxygen, with the production of ROS ${ }^{11}$ After electron transfer to oxygen, the redox catalyst is regenerated by spontaneous or enzyme-driven redox reaction. ${ }^{11}$

The impressive number of ongoing clinical trials that examine the therapeutic performance of novel redox drugs in cancer patients demonstrates that redox chemotherapy has attracted deep interest in the scientific community. ${ }^{8,9}$

Among these catalysts, compounds containing a chalcogen (ROS modulator) and a quinone (ROS generator), are particularly well suited to respond to the presence of OS,,$^{5,10-17}$ being interesting for the development of anti-cancer drugs. Their mechanisms of action depend on the environment, as they have the possibility to function as antioxidant in normal cells ${ }^{11}$ and as pro-oxidants in cells exposed to OS. ${ }^{14,17}$ If these agents are also able to adjust their activity in response to their redox environment in vivo, they might provide access to an important category of drugs.

Electrochemical methods are extraordinarily powerful and useful, in the characterization and design of redoxmodulating agents. ${ }^{5,18-21}$ They provide thermodynamic and kinetic molecular parameters, under different conditions that may be related to their biological activity in living cells and appear well adapted to explore redox pathways in vitro and the related in vivo studies. ${ }^{20,21}$ Thus, they have high relevance in the field of redox medicine.
As such, the present work focused on the electrochemical investigation, in aprotic medium, of eleven synthetic 3-substituted thio-nor-beta-lapachones (2-12) (Figure 1), which syntheses have been reported previously, ${ }^{22}$ except for 6, 10,11 and 12, which are novel compounds. We also, herein, present electroanalysis of their interaction with oxygen, along with the determination of cytotoxic activity against four cancer cell lines and a normal cell, in search for adequate selectivity index and aiming to correlating electrochemical and biological data. The mechanism of action based on ROS release is evaluated for the most active compound. The electrochemical features and biological activities of the precursor, nor-beta-lapachone (1), are included for comparison purposes.

Nor-beta-lapachone (1), a smaller homolog of betalapachone (13), can be easily prepared from nor-lapachol ${ }^{22}$ by acid catalysis. ${ }^{22,23}$ Sulfur has a variety of oxidation states and is highly versatile in function, ${ }^{24}$ thus, the interest in their synthetic coupling.

Other chalcogen-containing beta-lapachone's (13) scaffolds were synthesized and screened as cytotoxic compounds against several cancer cell lines, and some of them had been shown to be highly active and selective. ${ }^{14,25}$ Additional reports on antitumor thio-substituted quinones had appeared in the literature. ${ }^{12,26,27}$ Antimalarial and trypanocidal activities for this class of hybrid compounds were also reported. $22,28,29$

Up to our knowledge, there are few electrochemical reports on thionaphthoquinones, ${ }^{15,19,28,30-33}$ especially in aprotic medium. ${ }^{19,28,32-34}$ Most of the quinones and their intermediates, as well as reduced forms, exist inside hydrophobic cell membranes. As such, the aprotic polar dimethylformamide (DMF), dimethyl sulfoxide (DMSO) or acetonitrile are the solvents of choice, for electrochemical investigation. This is justified: (i) due to the necessity to mimic the nonpolar environment in the cell ${ }^{18-20,32,33}$ and (ii) to allow a single-electron transfer to generate the semiquinone, ${ }^{18-20}$ which is better obtained in absence of protons.

Based on the ever-increasing interest on biologically active quinones, with new strategies to increase selectivity, directing the compound to the target,,$^{35}$ the excitement

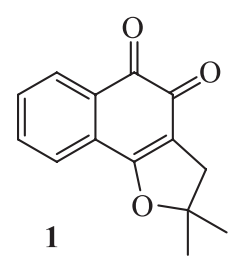

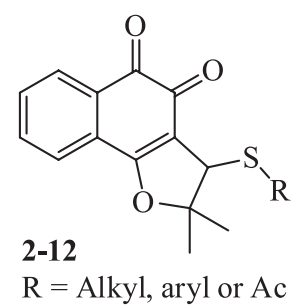<smiles>CC1(C)CCC2=C(O1)c1ccccc1C(=O)C2=O</smiles>

Figure 1. Chemical structures of the nor-beta-lapachone (1), studied thionaphthoquinones (2-12) and beta-lapachone (13). Ac: acetyl. 
toward their syntheses and knowledge of redox mechanisms continues. Theoretical and experimental approaches, together with evaluation of redox-based biological activity, in search for better prototypes, in the continuous fight against cancer and tropical diseases ${ }^{18-20}$ are welcome.

\section{Experimental}

\section{Reagents}

Extra-dry $N, N$-dimethylformamide (DMF, 99.8\%) was acquired from Acros Organics (Geel, Belgium), tetrabutylammonium hexafluorophosphate $\left(\mathrm{TBAPF}_{6}\right)$ and tetra- $N$-butylammonium fluoride (TBAP) and the other chemicals from Sigma-Aldrich (St. Louis, USA). TBAPF 6 was purified by recrystallization from absolute ethanol $(\times 3)$, and dried at reduced pressure, at $60{ }^{\circ} \mathrm{C}$. All the reagents were analytical grade. All the solutions were prepared using ultrapure water $(18.2 \mathrm{M} \Omega \mathrm{cm}$ ) from Milli-Q (Millipore Inc., Ziefen, Switzerland).

\section{Electrochemical studies}

Cyclic voltammetry (CV) and differential pulse voltammetry (DPV) experiments were performed with a conventional three electrode cell in an Autolab PGSTAT-30 potentiostat (Echo Chemie, Utrecht, The Netherlands) coupled to a PC microcomputer, using GPES 4.9 software.

\section{Reduction and oxidation studies}

The working electrode was a glassy carbon electrode (GCE) BAS $(\mathrm{d}=3 \mathrm{~mm})$, the counter electrode was a $\mathrm{Pt}$ wire and the reference electrode was an $\mathrm{Ag} \mid \mathrm{AgCl}$, $\mathrm{Cl}^{-}$(sat.). All electrodes were contained in a onecompartment electrochemical cell with a volumetric capacity of $10 \mathrm{~mL}$. GCE was cleaned up by polishing with alumina on a polishing felt (BAS polishing kit). In $\mathrm{CV}$ experiments, the scan rate varied from 10 to $500 \mathrm{mV} \mathrm{s}^{-1}$. Electrochemical reduction/oxidation was performed in aprotic media $\left(\mathrm{DMF}+\mathrm{TBAPF}_{6}\right.$, $\left.0.1 \mathrm{~mol} \mathrm{~L}^{-1}\right)$, at room temperature $\left(25 \pm 2{ }^{\circ} \mathrm{C}\right)$. Each compound $\left(1 \times 10^{-3} \mathrm{~mol} \mathrm{~L}^{-1}\right)$ was added to the supporting electrolyte, and the solution was deoxygenated with argon before each $\mathrm{CV}$ measurement. The quinones do not adsorb on the surface. It is only necessary to flush argon on the electrode surface between the runs. Different potential ranges were used from the cathodic to anodic scan. The most representative range was from 0 to $-3.0 \mathrm{~V}$ vs. $\mathrm{Ag} \mid \mathrm{AgCl}, \mathrm{Cl}^{-}$(sat.), in the cathodic direction and 0 to $+1.2 \mathrm{~V}$, in the anodic direction. For the
DPV measurements, the pulse amplitude was $50 \mathrm{mV}$, the pulse width, $70 \mathrm{~ms}$ and the scan rate, $5 \mathrm{mV} \mathrm{s}^{-1} .{ }^{20,26}$

\section{Experiments in the presence of oxygen}

To investigate the reactivity of the thionaphthoquinones (2-12) toward oxygen, electrochemical reductions, in aprotic medium (DMF + TBAP, $\left.0.1 \mathrm{~mol} \mathrm{~L}^{-1}\right)$, were performed in the presence and absence of oxygen. Oxygen was bubbled into the cell and its concentration was monitored by using an oxygen meter (Digimed DM-4, São Paulo, Brazil). CVs were recorded at different oxygen concentrations. The parameters analyzed were the anodic shift in the potential of the first reduction wave $\left(\mathrm{E}_{\mathrm{p}} \mathrm{I}_{\mathrm{c}}\right)$ and the current increase at the same peak $\left(\mathrm{I}_{\mathrm{p}} \mathrm{I}_{\mathrm{c}}\right)$ or decrease in the correspondent anodic peak $\left(\mathrm{I}_{\mathrm{p}} \mathrm{I}_{\mathrm{a}}\right)^{20,34-37}$ The apparent association constant for the reaction with oxygen $\left(\mathrm{k}_{\mathrm{ap}}\right)$ can be determined by equation $1 .{ }^{38}$

$I_{p c}=\frac{I_{p R}}{I_{p 0}}=\frac{k_{a p} R T\left[O_{2}\right]}{n F v}$

where, $\mathrm{I}_{\mathrm{pc}}=$ catalytic current; $\mathrm{I}_{\mathrm{pR}} / \mathrm{I}_{\mathrm{p} 0}=$ normalized current; $\mathrm{k}_{\mathrm{ap}}=$ apparent catalytic constant $\left(\mathrm{s}^{-1}\right) ; \mathrm{v}=$ scan rate $\left(\mathrm{V} \mathrm{s}^{-1}\right) ; \mathrm{n}=$ number of electrons; $\mathrm{F}=$ Faraday constant $\left(96485 \mathrm{C} \mathrm{mol}^{-1}\right)$; $\mathrm{T}=$ temperature $(298 \mathrm{~K})$ and $\mathrm{R}=8.314 \mathrm{~J} \mathrm{~mol}^{-1} \mathrm{~K}^{-1}$.

\section{Synthesis}

The reagents were purchased from Sigma-Aldrich (St. Louis, USA) and were used without further purification. Column chromatography was performed with silica gel 60 (Merck, 70-230 mesh). Analytical thin layer chromatography was performed with silica gel plates (Merck, Darmstadt, Germany, TLC silica gel $60 \mathrm{~F}_{254}$ ), and the plates were visualized using UV light. The indicated yields refer to homogeneous materials purified by chromatography and confirmed by spectroscopic techniques. Melting points were obtained on a Thermo scientific 9100 apparatus (Waltham, MA, USA) and were uncorrected. Infrared spectra were collected using $\mathrm{KBr}$ pellets on a PerkinElmer model 1420 FTIR spectrophotometer (Palo Alto, USA), and the spectra were calibrated relative to the $1601.8 \mathrm{~cm}^{-1}$ absorbance of polystyrene. ${ }^{1} \mathrm{H}$ and ${ }^{13} \mathrm{C}$ nuclear magnetic resonance (NMR) were recorded at room temperature using a Varian Mercury 300 or Varian Mercury $400 \mathrm{MHz}$ (Quebec, Canada), in DMSO- $d_{6}$. The chemical shift data were reported in units of $\delta(\mathrm{ppm})$ downfield from solvent, and the solvent was used as an internal standard; coupling constants $(J)$ are reported in hertz and refer to 
apparent peak multiplicities. High-resolution mass spectra (HRMS) were recorded on a MICROMASS Q-TOF mass spectrometer (Waters, Oconomowoc, WI, USA).

Compounds 6, 10-12 were synthesized for the first time and spectral data reported in the Supplementary Information section (SI, Figures S1-S4).

\section{General procedure for the preparation of 2-12}

In a $125 \mathrm{~mL}$ flask containing a solution of nor-lapachol (14) (500 mg, $2.2 \mathrm{mmol})$ in $40 \mathrm{~mL}$ dry chloroform, externally cooled with ice and under an inert atmosphere, bromine $(4.4 \mathrm{~mL}, 13.7 \mathrm{~g}, 8.59 \mathrm{~mol})$ was added. A red solid precipitate of the cationic ortho-quinone methide intermediate immediately formed, and the reaction mixture was left, under stirring conditions, for additional $10 \mathrm{~min}$. The excess bromine was removed under reduced pressure and $40 \mathrm{~mL}$ of chloroform was immediately added. The mixture was, then, externally cooled, in an ice bath. To this solution, a dry chloroform solution containing the appropriate thiol nucleophile (4.4 mmol in $25 \mathrm{~mL}$ ), was slowly added. The reaction mixture was stirred for $3 \mathrm{~h}$ and, then, poured into $50 \mathrm{~mL}$ of distilled water. The phases were separated and the organic phase washed with saturated sodium bicarbonate solution $(3 \times 50 \mathrm{~mL})$, distilled water $(3 \times 50 \mathrm{~mL})$, dried with anhydrous sodium sulfate, filtered and evaporated under reduced pressure. The resulting red solid, which was purified by flash column chromatography on silica gel, was eluted with gradient mixtures of hexane and ethyl acetate. The protocols for preparing 2-5 and 7-9 and the physical and spectroscopic data were previously reported. ${ }^{22}$

3-(4-(Methylthio)phenyl)thio-2,2-dimethyl-2,3-dihydronaphtho[1,2-b]furan-4,5-dione (6)

Isolated as an orange solid, in $83 \%$ yield; $m p 201-203^{\circ} \mathrm{C}$; IR $(\mathrm{KBr}) \vee / \mathrm{cm}^{-1} 2923,1658,1645,1614,1570,1476$, 1400, 1251, 1224, 1093, 1009, 791 (Figure S1, SI section); ${ }^{1} \mathrm{H}$ NMR $\left(\mathrm{CDCl}_{3}, 500 \mathrm{MHz}\right) 1.51\left(3 \mathrm{H}, \mathrm{s},(\mathrm{C}-2)-\mathrm{CH}_{3}\right), 1.81$ $\left(3 \mathrm{H}, \mathrm{s},(\mathrm{C}-2)-\mathrm{CH}_{3}\right), 2.43(3 \mathrm{H}, \mathrm{s}), 4.47(1 \mathrm{H}, \mathrm{s}), 7.13(2 \mathrm{H}, \mathrm{d}$, $J 8.5 \mathrm{~Hz}), 7.47(2 \mathrm{H}, \mathrm{d}, J 8.5 \mathrm{~Hz}), 7.57-7.67(1 \mathrm{H}, \mathrm{m}), 7.57-$ $7.67(1 \mathrm{H}, \mathrm{m}), 7.57-7.67(1 \mathrm{H}, \mathrm{m}), 8.08(1 \mathrm{H}, \mathrm{d}, J 7.0 \mathrm{~Hz})$ (Figure S2, SI section); ${ }^{13} \mathrm{C} \mathrm{NMR}\left(\mathrm{CDCl}_{3}, 125 \mathrm{MHz}\right) \delta 15.7$, 24.5, 28.7, 59.1, 95.9, 115.8, 125.1, 126.9, 127.6, 129.6, 131.1, 131.2, 132.4, 133.8, 134.6, 139.0, 168.5, 174.7, 180.7 (Figure S3, SI section); HRMS (electrospray ionization, ESI) $m / z,[\mathrm{M}+\mathrm{Na}]^{+}$calcd. for $\mathrm{C}_{21} \mathrm{H}_{18} \mathrm{O}_{3} \mathrm{~S}_{2} \mathrm{Na}^{+}$: 405.0590; found: 405.0594. $\Delta=1.0 \mathrm{ppm}$ (Figure $\mathrm{S} 4$, SI section).

3-(Benzylthio)-2,2-dimethyl-2,3-dihydronaphtho [1,2-b]furan-4,5-dione (10)

Compound 10 was isolated as an orange solid in $88 \%$ yield; mp 186-188 ${ }^{\circ} \mathrm{C}$; IR (KBr) v / cm ${ }^{-1} 1655,1644,1610$,
1585, 1568, 1403, 1247, 1223, 1082 (Figure S5, SI section); ${ }^{1} \mathrm{H}$ NMR $\left(\mathrm{CDCl}_{3}, 500 \mathrm{MHz}\right) \delta 1.38(3 \mathrm{H}, \mathrm{s}), 1.61(3 \mathrm{H}, \mathrm{s})$, 3.99 (2H, d, J 10.2 Hz), 4.09 (1H, s), 7.21-7.40 (3H, m), $7.38(2 \mathrm{H}, \mathrm{d}, J 7.5 \mathrm{~Hz}), 7.55-7.65(1 \mathrm{H}, \mathrm{m}), 7.55-7.65(1 \mathrm{H}$, $\mathrm{m}), 7.55-7.65(1 \mathrm{H}, \mathrm{m}), 8.07(1 \mathrm{H}, \mathrm{d}, J 7.8 \mathrm{~Hz}$ ) (Figure S6, SI section); ${ }^{13} \mathrm{C} \mathrm{NMR}\left(\mathrm{CDCl}_{3}, 125 \mathrm{MHz}\right) \delta 24.3,28.5,37.5$, 53.1, 95.4, 117.8, 124.9, 127.3, 127.7, 128.6, 129.3, 129.5, 131.1, 132.5, 132.3, 134.6, 138.1, 168.2, 175.1, 180.9 (Figure S7, SI section); HRMS (ESI) $m / z,[\mathrm{M}+\mathrm{Na}]^{+}$calcd. for $\mathrm{C}_{21} \mathrm{H}_{18} \mathrm{O}_{3} \mathrm{SNa}^{+}$: 373.0869; found: 373.0883. $\Delta=3.7 \mathrm{ppm}$ (Figure S8, SI section).

3-(Cyclohexylthio)-2,2-dimethyl-2,3-dihydronaphtho [1,2-b]furan-4,5-dione (11)

Compound 11 was isolated as an orange solid, in $81 \%$ yield; mp 155-156 ${ }^{\circ} \mathrm{C}$; IR (KBr) v / cm-1 2931, 2849, 1654, 1644, 1614, 1587, 1569, 1449, 1399, 1248, 1219, 1079 (Figure S9, SI section); ${ }^{1} \mathrm{H}$ NMR $\left(\mathrm{CDCl}_{3}, 500 \mathrm{MHz}\right)$ $\delta$ 1.20-1.40 (6H, m), $1.56(3 \mathrm{H}, \mathrm{s}), 1.71(3 \mathrm{H}, \mathrm{s}), 1.74-1.80$ (2H, m), 1.96-2.11 (2H, m), 3.06-3.15 (1H, m), $4.16(1 \mathrm{H}$, s), 7.55-7.65 $(1 \mathrm{H}, \mathrm{m}), 7.55-7.65(1 \mathrm{H}, \mathrm{m}), 7.55-7.65(1 \mathrm{H}$, $\mathrm{m}), 8.08$ (1H, dt, J7.3 and 1.1 Hz) (Figure S10, SI section); ${ }^{13} \mathrm{C} \mathrm{NMR}\left(\mathrm{CDCl}_{3}, 125 \mathrm{MHz}\right) \delta 24.4,25.7,25.9,26.1,28.4$, 33.4, 34.5, 45.1, 52.2, 95.2, 118.3, 124.7, 127.7, 129.3, 130.9, 132.0, 134.4, 167.8, 175.0, 180.9 (Figure S11, SI section); HRMS (ESI) $m / z,[\mathrm{M}+\mathrm{Na}]^{+}$calcd. for $\mathrm{C}_{20} \mathrm{H}_{22} \mathrm{O}_{3} \mathrm{SNa}^{+}$: 365.1182; found 365.1193. $\Delta=3.0 \mathrm{ppm}$ (Figure S12, SI section).

S-(2,2-Dimethyl-4,5-dioxo-2,3,4,5-tetrahydronaphtho [1,2-b]furan-3-yl)ethanethioate (12)

Compound 12 was isolated as an orange solid in $85 \%$ yield; $\mathrm{mp} 211-213{ }^{\circ} \mathrm{C}$; IR (KBr) v / cm ${ }^{-1} 1656,1645,1612$, 1586, 1569, 1492, 1400, 1223, 1080, 788 (Figure S13, SI section); ${ }^{1} \mathrm{H} \mathrm{NMR}\left(\mathrm{CDCl}_{3}, 500 \mathrm{MHz}\right) \delta 1.18(3 \mathrm{H}, \mathrm{s})$, $1.75(3 \mathrm{H}, \mathrm{s}), 2.04(3 \mathrm{H}, \mathrm{s}), 5.16(1 \mathrm{H}, \mathrm{s}), 7.71-7.80(1 \mathrm{H}, \mathrm{m})$, 7.71-7.80 (1H, m), 7.71-7.80 (1H, m), 8.18 (1H, d, J 8.3 and $1.5 \mathrm{~Hz}$ ) (Figure S14, SI section); ${ }^{13} \mathrm{C} \mathrm{NMR}\left(\mathrm{CDCl}_{3}\right.$, $125 \mathrm{MHz}) \delta 20.9,21.2,27.8,66.9,96.0,111.3,125.7$, $126.6,130.0,131.5,133.5,134.9,170.9,171.4,174.6$, 180.1 (Figure S15, SI section); HRMS (ESI) $m / z,[\mathrm{M}+\mathrm{Na}]^{+}$ calcd. for $\mathrm{C}_{16} \mathrm{H}_{14} \mathrm{O}_{4} \mathrm{SNa}^{+}$: 325.0505; found 325.0515 . $\Delta=3.1 \mathrm{ppm}$ (Figure S16, SI section).

\section{Evaluation of the cytotoxic activity by an in vitro assay}

Cell lines and culture

All the compounds were evaluated in vitro using the MTT assay against four cancer cell lines: SF295 (human glioblastoma), HCT-116 (human colon carcinoma), PC3 (prostate) and K562 (leukemia). Doxorubicin was used 
as a positive control. The selectivity of the compounds toward a normal proliferating cell line was investigated using the Alamar Blue assay with human peripheral blood mononuclear cells (PBMC), after $72 \mathrm{~h}$ of compound exposure. All cancer cell lines and PBMC were maintained in RPMI 1640 medium. All culture media were supplemented with $20 \%$ (PBMC) or 10\% (SF-295, HCT-116, PC3 and $\mathrm{K} 562$ ) fetal bovine serum, $2 \mathrm{mmol} \mathrm{L}^{-1} L$-glutamine, $100 \mathrm{IU} \mathrm{mL} \mathrm{L}^{-1}$ penicillin, $100 \mu \mathrm{g} \mathrm{mL} \mathrm{m}^{-1}$ streptomycin, at $37^{\circ} \mathrm{C}$ with $5 \% \mathrm{CO}_{2}$. PBMC cultures were also supplemented with $2 \%$ phytohaemagglutinin. In the cytotoxicity experiments, cells were plated in 96 -well plates $\left(0.1 \times 10^{6}\right.$ cells $p e r$ well for PC 3 and SF-295 cells, $0.3 \times 10^{6}$ cells per well, $0.7 \times 10^{5}$ cells per well for HCT-116 cells, and $1 \times 10^{6}$ cells per well for PBMC). All tested compounds were dissolved in DMSO. The final concentration of DMSO in the culture medium was kept constant $(0.1 \%$, v/v).

\section{Determination of cytotoxicity}

The cell viability was determined by the reduction of the yellow dye 3-(4,5-dimethyl-2-thiazol)-2,5-diphenyl$2 \mathrm{H}$-tetrazolium bromide (MTT) to a blue formazan product, as described. ${ }^{39}$ At the end of the incubation time $(72 \mathrm{~h})$, the plates were centrifuged and the medium was replaced with fresh medium $\left(200 \mathrm{~mL}\right.$ ) containing $0.5 \mathrm{mg} \mathrm{mL}^{-1}$ MTT. Three hours later, the MTT formazan product was dissolved in DMSO $(150 \mu \mathrm{L})$ and the absorbance was measured using a multiplate reader (DTX 880 Multimode Detector, Beckman Coulter, Inc. Fullerton, California, EUA). The compound effect was quantified as the percentage of control absorbance of the reduced dye at $595 \mathrm{~nm}$. The viability for PBMC cell was determined by the method of Alamar Blue. This incorporates a fluorometric/colorimetric growth indicator based on detection of metabolic activity. ${ }^{40}$ After $24 \mathrm{~h}$, compounds were added to each well, and the cells were incubated for $72 \mathrm{~h}$. Twenty four hours before the end of the incubation, $10 \mu \mathrm{L}$ of stock solution $\left(0.312 \mathrm{mg} \mathrm{mL}^{-1}\right)$ of Alamar Blue were added to each well. The absorbance was measured at 570 (reduced) and $595 \mathrm{~nm}$. All cell treatments were carried out with two replicates performed in triplicate. Values were computed using GraphPad Prism ${ }^{\circledR} 5.0$ program. $^{41}$

\section{Measurement of reactive oxygen species generation}

Intracellular reactive oxygen species (ROS) accumulation was monitored using 5-(6)-chloromethyl2', 7' -dichlorodihydrofluorescein diacetate (CM- $\mathrm{H}_{2}$ DCFDA), which is converted to the highly fluorescent dichlorofluorescein (DCF) in the presence of intracellular ROS. ${ }^{42}$ HCT-116 cells were pre-loaded with $10 \mu \mathrm{mol} \mathrm{L}{ }^{-1} \mathrm{CM}-\mathrm{H}_{2} \mathrm{DCFDA}$ and incubated for $40 \mathrm{~min}$ in the dark at $37{ }^{\circ} \mathrm{C} / 5 \% \mathrm{CO}_{2}$. After that time, the medium containing CM- $\mathrm{H}_{2}$ DCFDA was removed and the cells were washed twice with phosphate-buffered saline (PBS) buffer. From this stage, the cells were always protected from light. Fresh medium containing the compounds was then added and incubated at the times of interest (30 min, 1 and $3 \mathrm{~h}$ ). Cells were then harvested, washed and re-suspended in PBS and immediately analyzed by flow cytometry, using excitation and emission wavelengths of 490 and $525 \mathrm{~nm}$, respectively. Menadione (2-methyl-1,4-naphthoquinone) $\left(20 \mu \mathrm{mol} \mathrm{L}^{-1}\right)$ and hydrogen peroxide $\left(\mathrm{H}_{2} \mathrm{O}_{2}, 100 \mu \mathrm{mol} \mathrm{L}^{-1}\right)$ were used as positive controls. A total of 5,000 events were analyzed per sample. Data are expressed as mean \pm standard error of mean (SEM), from two independent experiments.

\section{Results and Discussion}

\section{Chemistry}

Initially, the synthesis of thionaphthoquinones $\mathbf{2 - 1 2}$, previously explored by our research group,,$^{22}$ involved the formation in situ of ortho-quinone methide $(o-\mathrm{QM})$ by reaction between nor-lapachol (14), in dry chloroform, and bromine under low temperature (ice bath) and nitrogen atmosphere. A red solid precipitate of the cationic $o-\mathrm{QM}$ intermediate immediately formed was reacted with $\mathrm{R}-\mathrm{SH}$ compound, resulting in a red solid, which was purified by flash column chromatography on silica gel (Figure 2). The structures of the synthesized compounds were confirmed by spectroscopic techniques (see SI section), such as ${ }^{1} \mathrm{H}$ and ${ }^{13} \mathrm{C}$ NMR, infrared spectroscopy and HRMS-ESI.

The analysis of ${ }^{1} \mathrm{H}$ NMR spectrum of compound 6 shows a signal at $4.47 \mathrm{ppm}$ from the methine hydrogen and the typical benzoaromatic pattern of 1,2-naphthoquinone isomers as three signals at 7.57-7.67 $(1 \mathrm{H}, \mathrm{m}, \mathrm{H}-7$ and $\mathrm{H}-8)$, 7.57-7.67 (1H, m, H-9), 8.08 (1H, d, J 7.0 Hz, H-6). On the other hand, the ${ }^{13} \mathrm{C}$ NMR spectrum displayed the signals at 174.7 and $180.7 \mathrm{ppm}$ for carbonyl groups.

\section{Electrochemical studies}

The reduction pathway is a function of parameters that may be directly associated with the acceptor molecule, such as the nature of the cleaving bond, the properties of substituents, and the redox potential of the leaving group, or externally driven by factors such as temperature, solvent, and the electrode potential (for heterogeneous reductions). ${ }^{43}$

The electrochemical reduction of quinones had been extensively studied and was shown to depend strongly on the reaction media. ${ }^{18,19,44}$

In typical measurements, CVs were recorded in aprotic medium (DMF + TBAPF, $\left.0.1 \mathrm{~mol} \mathrm{~L}^{-1}\right)$, at a scan 


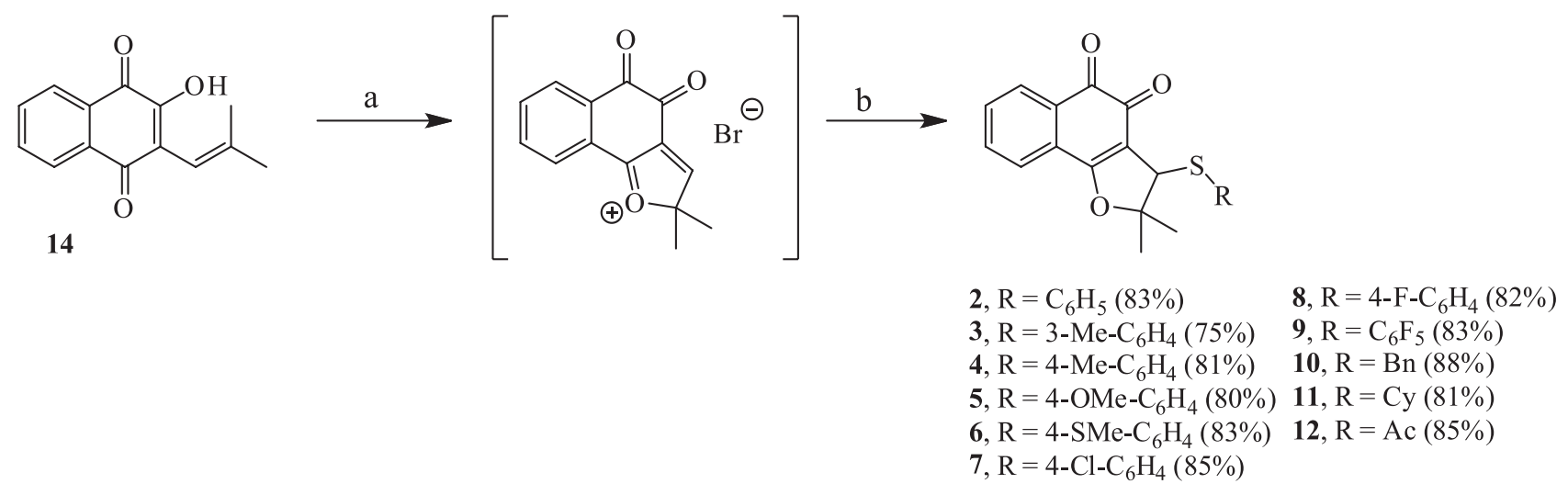

Figure 2. Scheme and chemical yields for the synthesis of thionaphthoquinones 2-12. (a) $\mathrm{Br}_{2}, \mathrm{CHCl}_{3} ;$ (b) R-SH. $\mathrm{Bn}=$ benzyl; $\mathrm{Cy}=$ cyclohexyl; $\mathrm{Ac}=\mathrm{acetyl}$.

Table 1. Electrochemical parameters for $\mathrm{CV}\left(\mathrm{DMF}+\mathrm{TBAPF}_{6}, 0.1 \mathrm{~mol} \mathrm{~L}^{-1}\right), \mathrm{GCE}, v=0.100 \mathrm{~V} \mathrm{~s}^{-1} v s . \mathrm{Ag}|\mathrm{AgCl}| \mathrm{Cl}^{-}$. QS represents the thionaphthoquinones

\begin{tabular}{lccccccccc}
\hline $\mathrm{QS}$ & $\mathrm{E}_{\mathrm{p}} \mathrm{I}_{\mathrm{c}} / \mathrm{V}$ & $\mathrm{E}_{\mathrm{p}} \mathrm{II}_{\mathrm{c}} / \mathrm{V}$ & $\mathrm{E}_{\mathrm{p}} \mathrm{III}_{\mathrm{c}} / \mathrm{V}$ & $\mathrm{E}_{\mathrm{p}} \mathrm{I}_{\mathrm{a}} / \mathrm{V}$ & $\mathrm{E}_{\mathrm{p}} \mathrm{II}_{\mathrm{a}} / \mathrm{V}$ & $\mathrm{E}_{\mathrm{p}} \mathrm{III}_{\mathrm{a}} / \mathrm{V}$ & $\mathrm{E}_{\mathrm{p}} \mathrm{IV}_{\mathrm{a}} / \mathrm{V}$ & $\mathrm{E}_{\mathrm{p}} \mathrm{IV}_{\mathrm{c}} / \mathrm{V}$ & $\mathrm{E}_{\mathrm{p}} \mathrm{V}_{\mathrm{c}} / \mathrm{V}$ \\
\hline $\mathbf{1}$ & -0.646 & -1.180 & - & -0.548 & -1.069 & - & - & - & - \\
$\mathbf{2}$ & -0.594 & -1.067 & -2.696 & -0.955 & -0.499 & +0.094 & 1.300 & -0.167 & 0.430 \\
$\mathbf{3}$ & -0.614 & -1.154 & -2.752 & -1.048 & -0.512 & +0.010 & 1.187 & -0.219 & 0.486 \\
$\mathbf{4}$ & -0.598 & -1.086 & -2.714 & -0.988 & -0.492 & +0.036 & 1.204 & -0.286 & 0.502 \\
$\mathbf{5}$ & -0.620 & -1.168 & -2.846 & -1.073 & -0.526 & -0.121 & 1.138 & -0.235 & 0.459 \\
$\mathbf{6}$ & -0.604 & -1.166 & -2.618 & -1.069 & -0.517 & -0.061 & 1.299 & -0.219 & 0.506 \\
$\mathbf{7}$ & -0.590 & -1.148 & -2.571 & -1.040 & -0.510 & -0.069 & 1.200 & -0.134 & 0.441 \\
$\mathbf{8}$ & -0.588 & -1.073 & -2.700 & -0.949 & -0.500 & +0.120 & 1.340 & -0.228 & 0.492 \\
$\mathbf{9}$ & -0.556 & -1.029 & -2.630 & -0.860 & -0.474 & +0.242 & 1.350 & -0.170 & 0.505 \\
$\mathbf{1 0}$ & -0.624 & -1.189 & -0.863 & -1.088 & -0.530 & - & 1.211 & -0.207 & 0.456 \\
$\mathbf{1 1}$ & -0.655 & -1.205 & -2.873 & -1.092 & -0.558 & - & 1.133 & -0.145 & 0.459 \\
$\mathbf{1 2}$ & -0.562 & -1.538 & -2.108 & -1.460 & -0.001 & +0.356 & 1.250 & -0.231 & 0.474 \\
\hline
\end{tabular}

$\mathrm{E}_{\mathrm{p}} \mathrm{I}_{\mathrm{c}}, \mathrm{E}_{\mathrm{p}} \mathrm{II}_{\mathrm{c}}, \mathrm{E}_{\mathrm{p}} \mathrm{III}_{\mathrm{c}}, \mathrm{E}_{\mathrm{p}} \mathrm{I}_{\mathrm{a}}, \mathrm{E}_{\mathrm{p}} \mathrm{II}_{\mathrm{a}}, \mathrm{E}_{\mathrm{p}} \mathrm{III}_{\mathrm{a}}, \mathrm{E}_{\mathrm{p}} \mathrm{IV}_{\mathrm{a}}, \mathrm{E}_{\mathrm{p}} \mathrm{IV}_{\mathrm{c}}, \mathrm{E}_{\mathrm{p}} \mathrm{V}_{\mathrm{c}}$ : peak potentials at $\mathrm{I}_{\mathrm{c}}, \mathrm{II}_{\mathrm{c}}, \mathrm{III}_{\mathrm{c}}, \mathrm{I}_{\mathrm{a}}, \mathrm{II}_{\mathrm{a}}, \mathrm{III}_{\mathrm{a}}, \mathrm{IV}_{\mathrm{a}}, \mathrm{IV}_{\mathrm{c}}, \mathrm{V}_{\mathrm{c}}$, respectively.

rate of $100 \mathrm{mV} \mathrm{s}^{-1}$. This enabled the determination of the electrochemical reduction (from +0.5 up to $-3.0 \mathrm{~V}$ ) and oxidation (from -0.5 up to $+1.5 \mathrm{~V}$ ) behaviors of each compound. Cathodic and anodic peak potentials for each compound are listed in Table 1.

The electrochemical study of the precursor, nor-betalapachone (1), was already reported ${ }^{35}$ in slightly different conditions (DMF + TBAP, $0.1 \mathrm{~mol} \mathrm{~L}^{-1}$ ). In the present case, its $\mathrm{CV}$, in DMF + TBAPF 6 , shows the presence of two sequential mono-electronic, diffusional-controlled $\left(\mathrm{E}_{\mathrm{p}} \mathrm{I}_{\mathrm{c}} \propto \mathrm{v}^{1 / 2}\right)$, quasi-reversible waves $\left(\mathrm{E}_{\mathrm{p}} \mathrm{I}_{\mathrm{c}}=-0.646 \mathrm{~V}\right.$; $\left.\mathrm{E}_{\mathrm{p}} \mathrm{II}_{\mathrm{c}}=-1.180 \mathrm{~V}\right)$. They correspond, as already known, to the generation of the semiquinone $\left(\mathrm{Q}^{*}\right)$, followed, in the second step, to the dianion $\left(\mathrm{Q}^{2-}\right)$ formation (Figure 3a). DPV experiments were also performed, showing two peaks (Figure 3b).

The $\mathrm{CV}$ of the thionaphthoquinones, represented by compound 2, displayed peaks in the cathodic (Figure 4a) and anodic regions (Figure $4 \mathrm{~b}$ ). Figure $4 \mathrm{c}$ is a combination of both regions and Figure $4 \mathrm{~d}$ shows the scan rate effect on the several reductions and oxidation waves, proving the diffusional and quasi-reversible nature of the electrochemical process. The CVs of the other thionaphthoquinones $(\mathbf{2 - 8}, \mathbf{1 1})$ are presented in the SI section (Figure S5) and are similar.

For the sake of simplicity, in the electrodic mechanism rationalization, the compounds are represented by [Q]-spH-SR, being spH a spacer, in this case, a dihydrofuranic ring, with a methynic carbon in the junction with the thioaromatic or thioaliphatic or thioacetate group; $\mathrm{SR}$ is an aromatic sulfide in the majority of cases and nonaromatic in three compounds (10-12). It is important to emphasize that both redox moieties (Q and SR) are not resonance-conjugated (the reason for writing $\mathrm{spH}$, between them), and behave as independent redox functions.

As expected, the overall CV profiles, in the first part of the cathodic region, for the thionaphthoquinones, are similar to the one reported for compound 1 (Figure 2) and other quinones (Figure S17, SI section). ${ }^{19,20,43}$ Two couples of cathodic and anodic peaks are monoelectronic, 

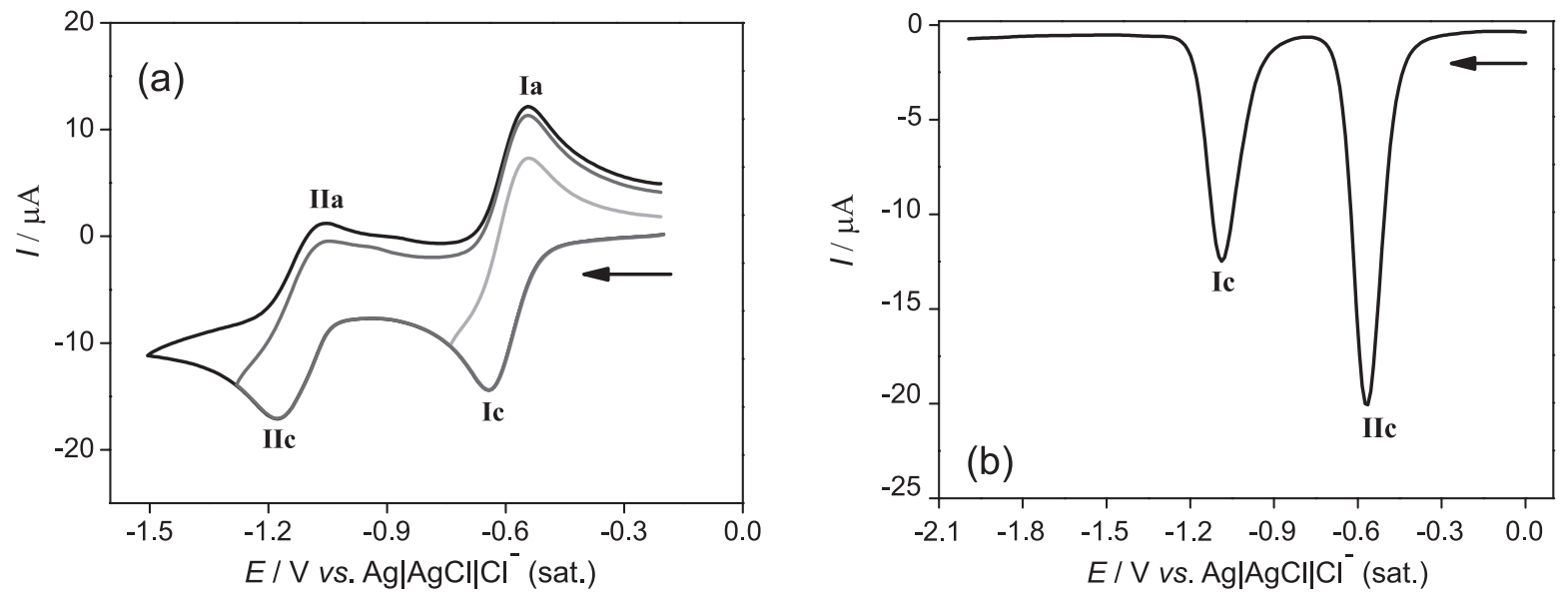

Figure 3. (a) Cyclic voltammetry $(\mathrm{CV})$ of nor-beta-lapachone $(\mathbf{1})\left(1 \mathrm{mmol} \mathrm{L}^{-1}\right)$ in $\mathrm{DMF}+\mathrm{TBAPF}_{6}\left(0.1 \mathrm{~mol} \mathrm{~L}^{-1}\right), \mathrm{GCE}, \mathrm{v}=100 \mathrm{mV} \mathrm{s}{ }^{-1}$. Several inversion potentials in the CV of 1; (b) differential pulse voltammetry (DPV) curve of $\mathbf{1}\left(1 \mathrm{mmol} \mathrm{L}^{-1}\right)$ at the same conditions, during reduction process. Potential range from 0 to $-2.0 \mathrm{~V}$, with a pulse amplitude of $50 \mathrm{mV}$ and a sample pulse width of $70 \mathrm{~ms}, \mathrm{v}=10 \mathrm{mV} \mathrm{s}$. Arrow indicates initial scan direction.
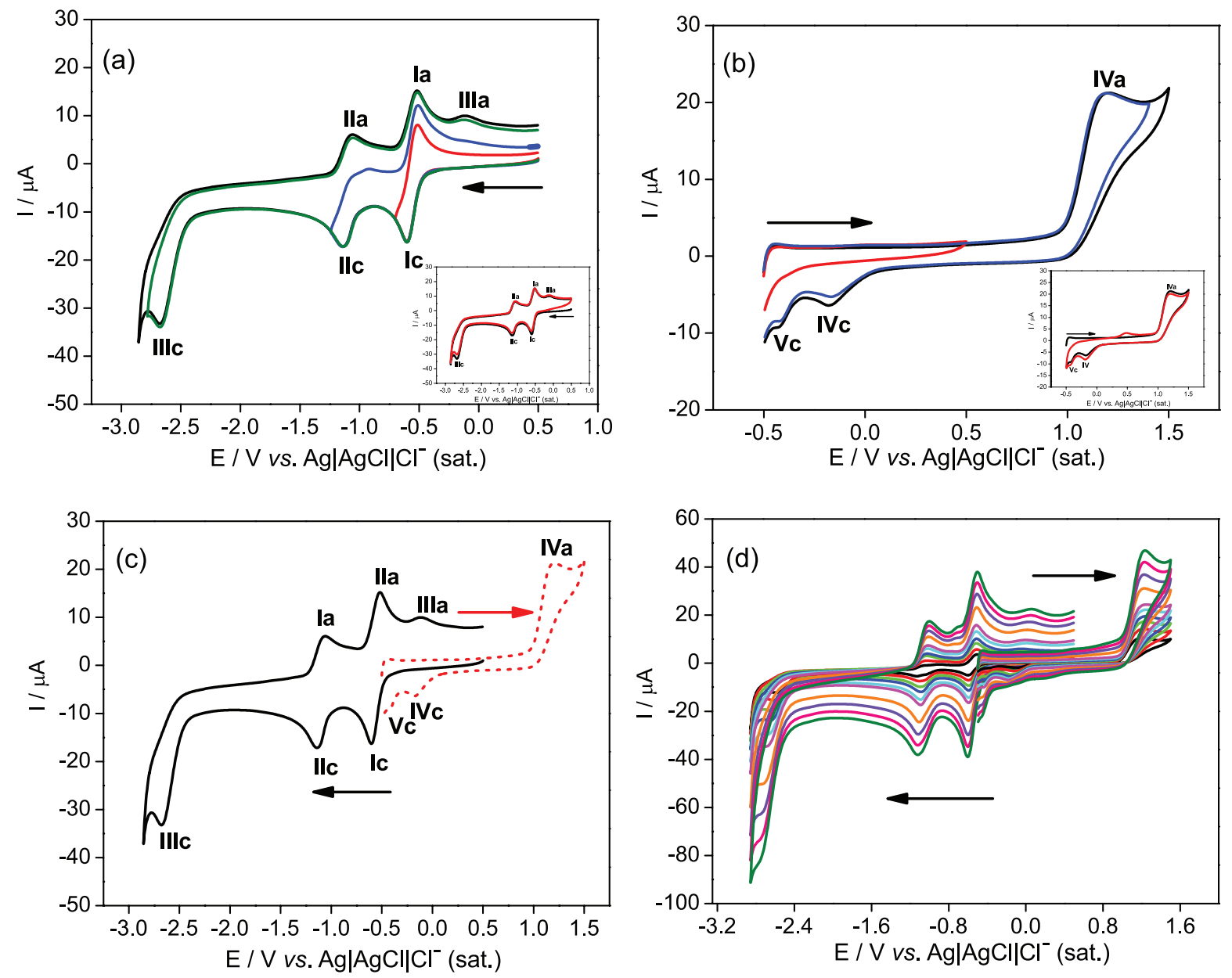

Figure 4. Cyclic voltammetry $(\mathrm{CV})$ of $2\left(1 \mathrm{mmol} \mathrm{L}^{-1}\right)$ in DMF $+\mathrm{TBAPF}_{6}\left(0.1 \mathrm{~mol} \mathrm{~L}^{-1}\right), \mathrm{GCE}, \mathrm{v}=100 \mathrm{mV} \mathrm{s}{ }^{-1}$. (a) Cathodic and (b) anodic direction. Several inversion potentials in the $\mathrm{CV}$ of $\mathbf{2}$; inserts: successive CVs; (c) cathodic direction (black line) and anodic direction (red dashed line); (d) different scan rates: $10,20,35,50,75,100,200,300,400$ and $500 \mathrm{mV} \mathrm{s}^{-1}$.

diffusional $\left(\mathrm{E}_{\mathrm{p}} \mathrm{I}_{\mathrm{c}} \propto \mathrm{v}^{1 / 2}\right)$ and have quasi-reversible nature $\left(\mathrm{I}_{\mathrm{c}} / \mathrm{I}_{\mathrm{a}}\right)$. As well-known, the first pair is related to the anionradical (semiquinone) formation, and the second pair of peaks is broader and less-defined $\left(\mathrm{II}_{\mathrm{c}} / \mathrm{II}_{\mathrm{a}}\right)$, as observed before ${ }^{43}$ due to possible chemical reactions of the orthosemiquinones. A number of deviations from ideal behavior 
have been identified, some readily interpretable and others of completely unknown origin. ${ }^{43}$

The values of $E_{p} I_{c}$ varied from -0.556 (9, pentafluorobenzene derivative) up to $-0.655 \mathrm{~V}$, for the cyclohexyl one (11) (Table 1).

The CVs of compounds 9 and 12, which substituents are a pentafluorobenzene and a non-aromatic thioacetate,

(a)

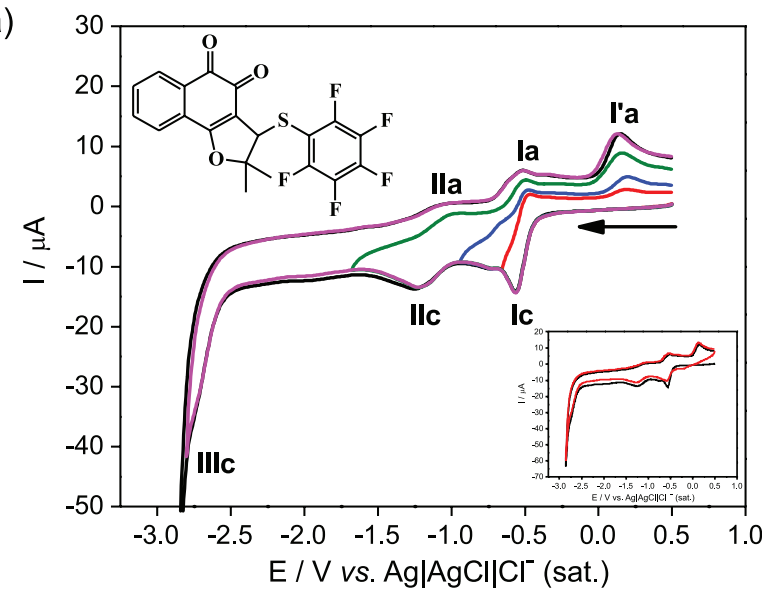

(b)

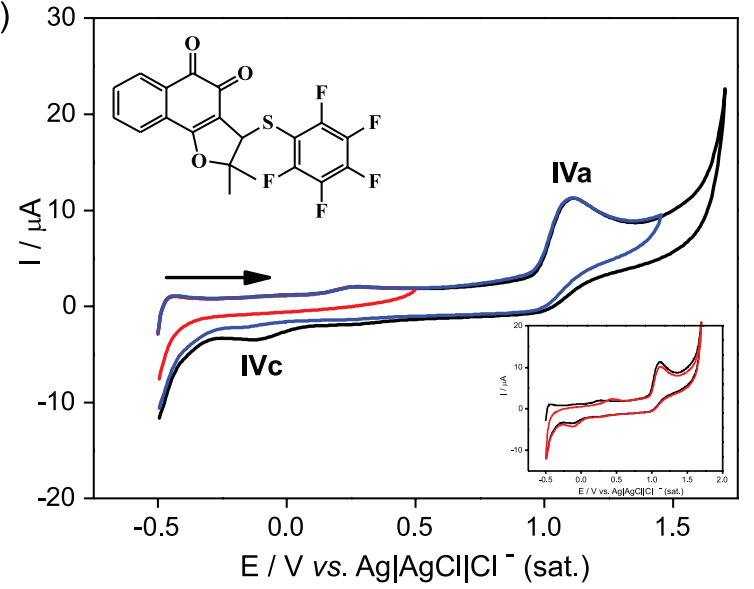

(c)

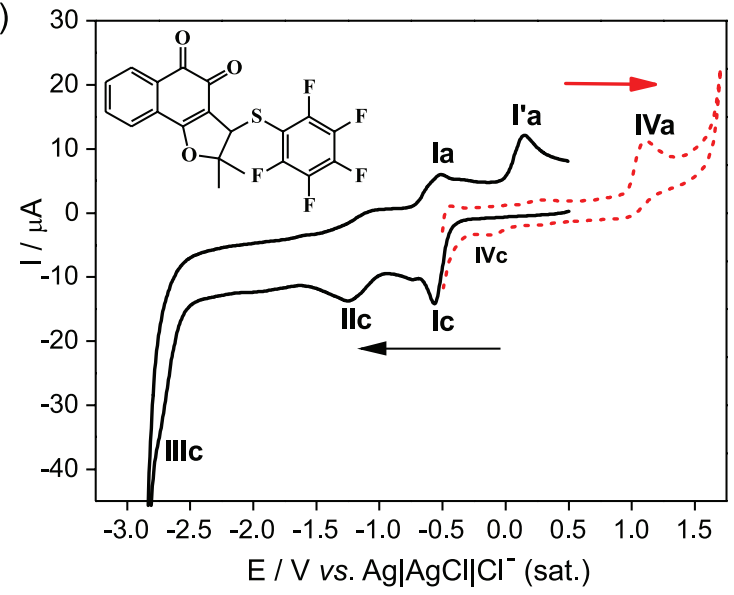

respectively (Figure 5), display a different profile (Figures $5 \mathrm{a}$ and $5 \mathrm{~b}$ ). Wave $\mathrm{II}_{\mathrm{c}}$ for compound 9 is broader than for compounds $\mathbf{1 - 8}$, with an additional shoulder, which always appears in the presence of halogenated compounds. For compound 12, several other reduction waves appear, being the first wave more prominent than the other ones. The complexity of the $\mathrm{CV}$ profile may
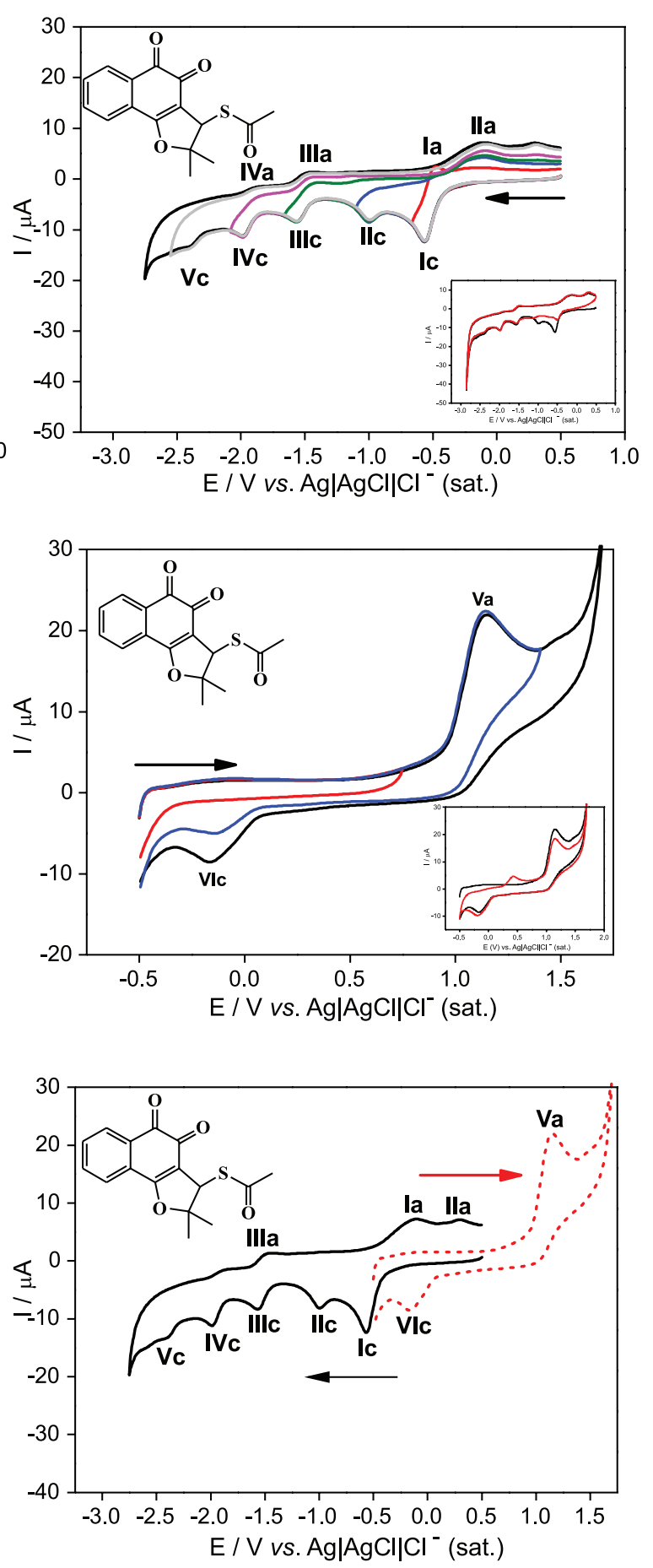

Figure 5. Cyclic voltammetry (CV) of $\mathbf{9}$ (left) and $\mathbf{1 2}$ (right) $\left(1 \mathrm{mmol} \mathrm{L}^{-1}\right)$ in DMF + TBAPF 6 ( $\left.0.1 \mathrm{~mol} \mathrm{~L}^{-1}\right), \mathrm{GCE}, v=100 \mathrm{mV} \mathrm{s}^{-1}$. (a) Cathodic and (b) anodic direction-several inversion potentials in the CVs of $\mathbf{9}$ and $\mathbf{1 2}$; inserts: successive CVs; (c) cathodic direction (black line) and anodic direction (red dashed line). 
indicate bond cleavage, generating other electroactive systems ${ }^{20}$ and lack of stability. In the oxidation region, for compound 12, the behavior is similar to the other thionaphthoquinones, while for $\mathbf{9}$, the anodic wave is smaller than in all other cases, suggesting a monoelectronic oxidation leading to a cation-radical, which suffers dimerization, due to the electron-withdrawing characteristics of the perfluorinated ring.

For the complete set of thionaphthoquinones, a third irreversible reduction wave appears, with more negative potentials (Figure S5, SI section) (Table 1) and more intense current, related to the capture of 2 electrons. These peaks are irreversible at all scan rates investigated and broaden as $v$ increases. Previous works by Maran and co-workers ${ }^{44,45}$ reported similar behavior for diphenylmethyl paramethoxyphenyl sulfide, with occurrence of $\mathrm{C}-\mathrm{S}$ bond cleavage and self-protonation mechanisms. ${ }^{46}$ In our case, the last mechanism does not occur, due to the lack of dissociable acidic functions, however, protonation is possible in the generated carbanion function, due to residual water or proton capture from the supporting electrolyte, by Hoffman elimination.

A possible mechanism is represented by equations 2-4. The thiophenolate ion (-SR) can be oxidized at $\mathrm{III}_{\mathrm{a}}$, a small shoulder present in all the CVs, which only appear at potential reversal close to III $_{\mathrm{c}}$ (equations 5-6).

[Q]-spH-SR + e- $\leftrightarrows\left[\mathrm{Q}^{*}\right]-\mathrm{spH}-\mathrm{SR}$

$\left[\mathrm{Q}^{*}\right]-\mathrm{spH}-\mathrm{SR}+\mathrm{e}^{-} \leftrightarrows\left[\mathrm{Q}^{2-}\right]-\mathrm{spH}-\mathrm{SR}$

$\left[\mathrm{Q}^{2-}\right]-\mathrm{spH}-\mathrm{SR}+2 \mathrm{e}^{-} \rightarrow\left[\mathrm{Q}^{2-}\right]-\mathrm{spH}-\mathrm{H}+{ }^{-\mathrm{SR}}$

$-\mathrm{SR} \rightarrow \cdot \mathrm{SR}+\mathrm{e}$

$2 \cdot \mathrm{SR} \rightarrow \mathrm{RSSR}$

As the S-phenyl moiety is not resonance-conjugated with the reducible naphthoquinone moiety, there is only a slight change in the reduction potentials for the majority of compounds. The difference of $100 \mathrm{mV}$ was observed between compound $\mathbf{9}\left(-\mathrm{C}_{6} \mathrm{~F}_{5}\right)$, the most easily reduced and the aliphatic $\mathrm{S}$ derivative (11), reduced at more negative potentials.

The electron withdrawing substituents are $\mathrm{Cl}$ $\left(\sigma_{\mathrm{Cl}}=0.22\right), \mathrm{F}\left(\sigma_{\mathrm{F}}=0.06\right)$, while electron donating ones are para-methyl $\left(\sigma_{\mathrm{CH} 3}=-0.17\right)$, meta-methyl $\left(\sigma_{\mathrm{CH}_{3}}=-0.06\right)$ and methoxy $\left(\sigma_{\mathrm{OCH} 3}=-0.28\right)$, among others.

The electrophilicity order for the present compounds, represented by $E_{\mathrm{p}} \mathrm{I}_{\mathrm{c}}$ values, is: $9(-0.556 \mathrm{~V})$ ca. $12(-0.562 \mathrm{~V})<8(-0.588 \mathrm{~V})$ ca. $7(-0.590 \mathrm{~V})$ ca.
$2(-0.594 \mathrm{~V})$ ca. $4(-0.598 \mathrm{~V})$ ca. $6(-0.604 \mathrm{~V})<$ $3(-0.614 \mathrm{~V})$ ca. $5(-0.620 \mathrm{~V})$ ca. $10(-0.624 \mathrm{~V})<$ $11(-0.655 \mathrm{~V})$.

In the anodic region of all the quinones (Figures 4 and 5, Figure S5, SI section), a sharp, irreversible peak $\left(\mathrm{IV}_{\mathrm{a}}\right)$ appears. The currents of these anodic peaks vary with the structure.

In the case of compound $\mathbf{2}$, the intensity of the anodic peak $\left(\mathrm{IV}_{\mathrm{a}}\right)$ is, at least, twice higher, in relation to the first reduction peak $\left(I_{c}\right)$ (Figure 4c). In the reversed cycle, two new reduction waves $\left(\mathrm{IV}_{\mathrm{c}}\right.$ and $\left.\mathrm{V}_{\mathrm{c}}\right)$ are observed close to $0 \mathrm{~V}$; in the successive scan, it is observed that the reduced product formed at $\mathrm{IV}_{\mathrm{c}}$ can be re-oxidized ( $\mathrm{IV}_{\mathrm{a}}{ }^{\prime}$ ) (Figure $4 \mathrm{~b}$, insert).

The quite high oxidation potential of the 3-phenylthiodihydronaphtho[1,2- $b]$ furan-4,5-diones attests that the sulfur atom is the first part of the molecule to be oxidized to mono- and di-positive ions, which interact further with anions or with the starting materials. ${ }^{46-48}$ The phenyl moiety is involved in charge delocalization only if it is substituted with strong electron donating groups, ${ }^{47,49}$ as is the case of compound $\mathbf{5}$, in which, the anodic peak $\mathrm{IV}_{\mathrm{a}}$ is followed by a more positive one $\left(\mathrm{V}_{\mathrm{a}}\right)$ (Figure S16, SI section).

The products of the electrochemical oxidation of alkylarylsulfides (RSAr) are strongly dependent upon the structure of the alkyl/aryl group linked to it, as well as by the nature of the electrolysis medium and the water content of the solvent. ${ }^{48,49}$

The first mono-electronic capture leads to the formation of the corresponding $\mathrm{S}$ radical-cation, for which four reaction paths are generally available: deprotonation; nucleophilic attack at sulfur; irreversible $\mathrm{C}-\mathrm{S}$ bond cleavage and nucleophilic attack at the aromatic ring. The relative weight of each of these reaction pathways is governed by the facts already mentioned. ${ }^{47-49}$ It shows a simple CV for a very complex mechanism. It will be further explored, but in summary, it can be represented by the usual pathways ${ }^{49-51}$ (Figure 6), as discussed in the previous paragraph.

The electrochemical oxidation profile, based on the values of $\mathrm{E}_{\mathrm{p}} \mathrm{IV}_{\mathrm{a}}$ (Table 1, column 9), is related to effects of the substituents, with oxidation facilitated by electron donating ones.

The order of oxidation facility is: $\mathbf{1 1}(1.133 \mathrm{~V})>$ $\mathbf{5}(1.138 \mathrm{~V})>\mathbf{3}(1.187 \mathrm{~V})>\mathbf{7}(1.200 \mathrm{~V})$ ca. $\mathbf{4}(1.204 \mathrm{~V})>$ $\mathbf{1 0}(1.211 \mathrm{~V})>\mathbf{1 2}(1.250 \mathrm{~V})>\mathbf{6}(1.299 \mathrm{~V})$ ca. $\mathbf{2}(1.300 \mathrm{~V})$ $>\mathbf{8}(1.340 \mathrm{~V})>\mathbf{9}(1.350 \mathrm{~V})$.

\section{Reactivity with oxygen}

The investigation of the interaction of oxygen with quinones and respective radical anions can be performed 


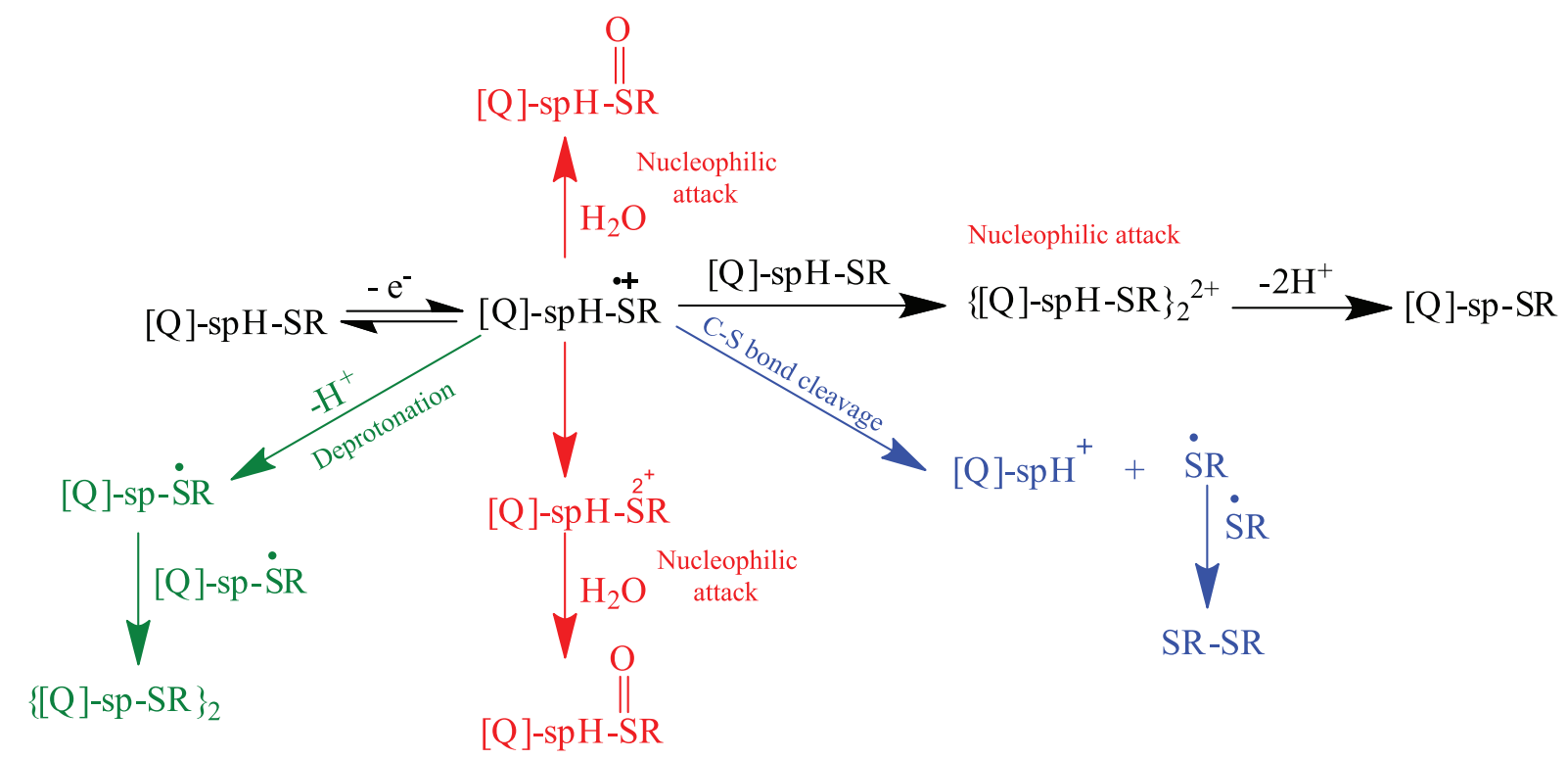

Figure 6. Putative pathways for the oxidation of thionaphthoquinones.

through cyclic voltammetry, in aprotic media. ${ }^{18-20,36-38}$ It mimics one of the most important mechanisms of molecular action of quinones, particularly, the generation of ROS after reduction and electron transfer to oxygen. 18-20,36,37

Non-aqueous polar solvents are chosen as better models of a membrane environment, in which peroxidation processes take place. Both the superoxide anion radical and its conjugated acid, the hydroperoxyl radical, are long-lived species in aprotic media ${ }^{50,51}$ and unstable in water and other protic solvents, owing to their fast disproportionation. ${ }^{52,53}$ In DMF or DMSO, $\mathrm{O}_{2}{ }^{-}$is a long-lived species and stable even at low-scan-rate voltammetry.

The electrochemical behavior of compound $\mathbf{2}$, in presence of oxygen is displayed in Figure 7. All the thionaphthoquinones have a similar feature, with different catalytic constants. Additional graphs are presented in the SI section (Figure S18).

With the successive bubbling of oxygen, the voltammetric profile relative to the first monoelectronic reduction wave changes. A positive slight shift of the cathodic potential and an increase of the reduction current occur as the oxygen concentration increases, with a concomitant disappearance of the anodic peak. This finding evidences reaction of the semiquinone with oxygen, in a homogeneous catalytic electron transfer (Figure 7, equations 2 and 7).

$\left[\mathrm{Q}^{*}\right]-\mathrm{spH}-\mathrm{SR}+\mathrm{O}_{2} \rightarrow[\mathrm{Q}]-\mathrm{spH}-\mathrm{SR}+\mathrm{O}_{2} \cdot$

Data obtained from the addition of different concentrations of oxygen (Figure 7 and insert) allow to determine the apparent association constants between the electrogenerated semiquinones and $\mathrm{O}_{2}$ from the graph

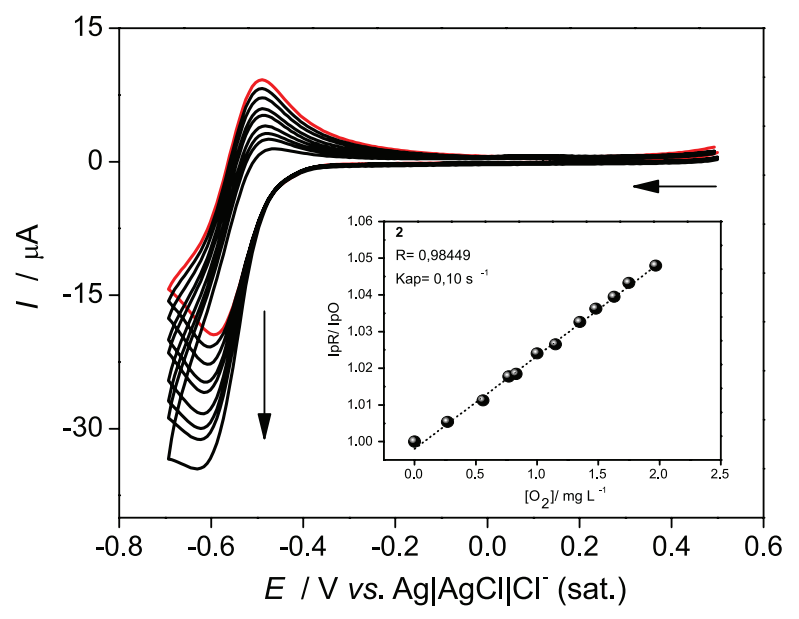

Figure 7. $\mathrm{CV}$ for 2 , in DMF + TBAP $\left(0.1 \mathrm{~mol} \mathrm{~L}^{-1}\right), \mathrm{GCE}, v=50 \mathrm{mV} \mathrm{s}^{-1}$, cathodic direction. $\mathrm{CV}$ in absence (red line) and in presence (black lines) of different concentrations of oxygen. Potential range: from $0.5 \mathrm{~V}$ up to $-0.7 \mathrm{~V}$. Insert: Linear portion of $\mathrm{I}_{\mathrm{pR}} / \mathrm{I}_{\mathrm{pO}}$ in function of oxygen concentration.

$\mathrm{I}_{\mathrm{plc}} / \mathrm{I}_{\mathrm{pO} 1} v s . \mathrm{k}_{\mathrm{ap}}\left[\mathrm{O}_{2}\right] \mathrm{RT} / \mathrm{nFv}$, considering that the maximum solubility of oxygen in DMF is $1.85 \mathrm{mmol} \mathrm{L}^{-1}$ at $25^{\circ} \mathrm{C}$.

The $\mathrm{k}_{\mathrm{ap}}$ obtained can be related to the capacity of generation of superoxide anion radical. The respective constants of interaction with oxygen, together with the compound number, are listed in increasing order of reactivity: $3\left(0.06 \mathrm{~s}^{-1}\right)<\mathbf{4}\left(0.10 \mathrm{~s}^{-1}\right)$ ca. $2\left(0.11 \mathrm{~s}^{-1}\right)$ ca. $8\left(0.12 \mathrm{~s}^{-1}\right)<\mathbf{6}\left(0.18 \mathrm{~s}^{-1}\right)<\mathbf{5}\left(0.32 \mathrm{~s}^{-1}\right)<7\left(0.69 \mathrm{~s}^{-1}\right)$.

Comparing with other quinones, ${ }^{34}$ using the same method, the present values, except for 7 (4-Cl derivative), are much lower than the ones obtained for arylated and dihydrofuran naphthoquinones, which showed values in the range of 0.45 up to $1.03 \mathrm{~s}^{-1},{ }^{34}$ and correlated well with ROS release in cancer cells. This may be a hint about the 
mechanism, not entirely controlled by oxidative stress, like reported before for the pterocarpanequinone LQB 118 $\left(\left(7 \mathrm{a} S^{*}, 12 \mathrm{a} S^{*}\right)-7,7 \mathrm{a}\right.$-dihydro-5H-benzo[g]benzofuro[3,2-c] chromene-5,13(12aH)-dione) ${ }^{20}$ which presented kinetic data similar to the present ones $\left(0.17 \mathrm{~s}^{-1}\right)$.

\section{Biological results}

Eleven thionaphthoquinones were assayed against four human tumor cell lines, SF-295 (human glioblastoma), HCT-116 (human colon carcinoma), PC3 (prostate) and K562 (leukemia) and towards PBMC (peripherical blood mononuclear cell), using effective concentration that leads to the death of $50 \%$ of the cells $\left(\mathrm{IC}_{50}\right)$.

The compounds were classified according to their activity as highly active $\left(\mathrm{IC}_{50}<2 \mu \mathrm{M}\right.$, moderately active $\left(2 \mu \mathrm{M}<\mathrm{IC}_{50}<10 \mu \mathrm{M}\right)$ or inactive $\left(\mathrm{IC}_{50}>10 \mu \mathrm{M}\right){ }^{54}$

Table 2 lists the values of the cytotoxic activity $\left(\mathrm{IC}_{50}\right)$ in $\mu \mathrm{g} \mathrm{mL} \mathrm{m}^{-1}(\mu \mathrm{M})$ of nor-beta-lapachone (1), already described, ${ }^{55}$ doxorubicin, along with new data from the 11 thionaphthoquinones, with the respective $95 \%$

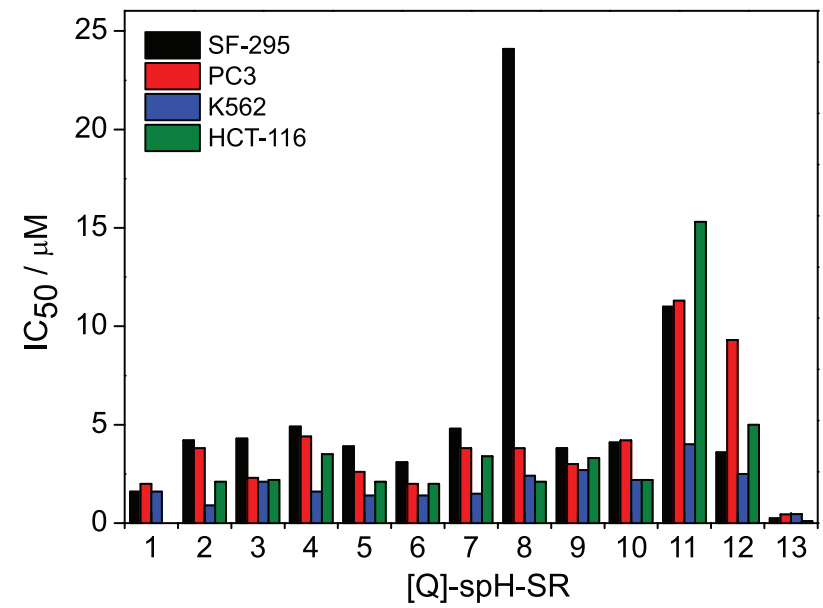

Figure 8. Graph showing $\mathrm{IC}_{50}$ values $(\mu \mathrm{M})$ of the thionaphthoquinones ([Q]-spH-SR) (1-12), for the 4 cancer lines studied, in comparison with doxorubicin (13).

confidence interval. Figure 8 allows a better comparative analysis.

Analysis of Table 2 and Figure 8, with the results of $\mathrm{IC}_{50}$, allows to evidence that all the hybrid compounds have

Table 2. Cytotoxic activity $\left(\mathrm{IC}_{50}\right)$ of 1-12 and doxorubicin against human tumor cell lines and towards PBMC

\begin{tabular}{|c|c|c|c|c|c|}
\hline \multirow[b]{2}{*}{ Compound } & \multicolumn{5}{|c|}{$\mathrm{IC}_{50}$ (inside parentheses in $\left.\mu \mathrm{M}\right) /\left(\mu \mathrm{g} \mathrm{mL} \mathrm{L}^{-1}\right)$} \\
\hline & $\begin{array}{c}\text { SF-295 } \\
\text { (glioblastoma) }\end{array}$ & $\begin{array}{c}\text { PC3 } \\
\text { (prostate) }\end{array}$ & $\begin{array}{c}\text { K562 } \\
\text { (leukemia) }\end{array}$ & $\begin{array}{c}\text { HCT-116 } \\
\text { (colon carcinoma) }\end{array}$ & $\begin{array}{l}\text { PBMC } \\
\text { (normal) }\end{array}$ \\
\hline 1 & $\begin{array}{c}(1.58)^{56} \\
(1.31-1.88)\end{array}$ & $\begin{array}{c}(1.98)^{57} \\
(1.53-2.23)\end{array}$ & $\begin{array}{c}(1.62)^{57} \\
(1.44-1.79)\end{array}$ & - & $>(21.9)^{56}$ \\
\hline 2 & $\begin{array}{l}1.43(4.2) \\
0.62-3.26\end{array}$ & $\begin{array}{l}1.28(3.8) \\
1.16-1.40\end{array}$ & $\begin{array}{l}0.31(0.9) \\
0.28-0.35\end{array}$ & $\begin{array}{l}0.71(2.1) \\
0.62-0.82\end{array}$ & $\begin{array}{l}1.19(3.5) \\
1.07-1.33\end{array}$ \\
\hline 3 & $\begin{array}{l}1.52(4.3) \\
0.94-2.45\end{array}$ & $\begin{array}{l}0.81(2.3) \\
0.70-0.93\end{array}$ & $\begin{array}{l}0.73(2.1) \\
0.68-0.78\end{array}$ & $\begin{array}{l}0.77(2.2) \\
0.66-0.89\end{array}$ & $\begin{array}{l}1.16(3.3) \\
1.07-1.27\end{array}$ \\
\hline 4 & $\begin{array}{l}1.72(4.9) \\
1.57-1.89\end{array}$ & $\begin{array}{l}1.53(4.4) \\
1.39-1.68\end{array}$ & $\begin{array}{l}0.57(1.6) \\
0.51-0.64\end{array}$ & $\begin{array}{l}1.22(3.5) \\
1.10-1.35\end{array}$ & $\begin{array}{l}1.66(4.7) \\
1.52-1.81\end{array}$ \\
\hline 5 & $\begin{array}{l}1.42(3.9) \\
0.92-2.20\end{array}$ & $\begin{array}{l}0.97(2.6) \\
0.83-1.14\end{array}$ & $\begin{array}{l}0.53(1.4) \\
0.40-0.69\end{array}$ & $\begin{array}{l}0.76(2.1) \\
0.70-0.81\end{array}$ & $\begin{array}{l}1.73(4.7) \\
1.56-1.93\end{array}$ \\
\hline 6 & $\begin{array}{c}1.18(3.09) \\
0.94-1.48\end{array}$ & $\begin{array}{l}1.41(2.0) \\
1.26-1.58\end{array}$ & $\begin{array}{l}0.53(1.4) \\
0.48-0.59\end{array}$ & $\begin{array}{l}0.76(2.0) \\
0.64-0.89\end{array}$ & $\begin{array}{l}1.58(4.1) \\
1.42-1.77\end{array}$ \\
\hline 7 & $\begin{array}{l}1.79(4.8) \\
1.62-1.98\end{array}$ & $\begin{array}{l}1.40(3.8) \\
1.27-1.54\end{array}$ & $\begin{array}{l}0.55(1.5) \\
0.51-0.60\end{array}$ & $\begin{array}{l}1.25(3.4) \\
1.06-1.47\end{array}$ & $\begin{array}{l}1.44(3.9) \\
1.30-1.60\end{array}$ \\
\hline 8 & $\begin{array}{c}8.54(24.1) \\
7.82-9.34\end{array}$ & $\begin{array}{l}1.33(3.8) \\
1.20-1.48\end{array}$ & $\begin{array}{l}0.85(2.4) \\
0.76-0.95\end{array}$ & $\begin{array}{l}0.74(2.1) \\
0.63-0.87\end{array}$ & $\begin{array}{l}1.96(5.5) \\
1.58-2.42\end{array}$ \\
\hline 9 & $\begin{array}{l}1.61(3.8) \\
1.22-2.12\end{array}$ & $\begin{array}{l}1.30(3.0) \\
1.11-1.52\end{array}$ & $\begin{array}{l}1.14(2.7) \\
0.88-1.48\end{array}$ & $\begin{array}{l}1.41(3.3) \\
1.20-1.67\end{array}$ & $\begin{array}{l}1.39(3.3) \\
1.28-1.50\end{array}$ \\
\hline 10 & $\begin{array}{l}1.45(4.1) \\
0.80-2.65\end{array}$ & $\begin{array}{l}1.47(4.2) \\
1.32-1.64\end{array}$ & $\begin{array}{l}0.76(2.2) \\
0.67-0.86\end{array}$ & $\begin{array}{l}0.76(2.2) \\
0.70-0.82\end{array}$ & $\begin{array}{l}1.86(5.3) \\
1.68-2.07\end{array}$ \\
\hline 11 & $>10$ & $\begin{array}{c}3.88(11.3) \\
2.95-5.11\end{array}$ & $\begin{array}{l}1.38(4.0) \\
1.11-1.73\end{array}$ & $\begin{array}{c}5.24(15.3) \\
5.00-5.49\end{array}$ & $\begin{array}{l}1.35(3.9) \\
1.25-1.47\end{array}$ \\
\hline 12 & $\begin{array}{l}1.10(3.6) \\
0.84-1.44\end{array}$ & $\begin{array}{l}2.81(9.3) \\
2.49-3.16\end{array}$ & $\begin{array}{l}0.77(2.5) \\
0.65-0.90\end{array}$ & $\begin{array}{l}1.52(5.0) \\
1.31-1.77\end{array}$ & $\begin{array}{l}1.82(6.0) \\
1.66-1.98\end{array}$ \\
\hline Doxorubicin & $\begin{array}{c}0.15(0.25) \\
0.12-0.18\end{array}$ & $\begin{array}{c}0.26(0.44) \\
0.20-0.27\end{array}$ & $\begin{array}{c}0.27(0.46) \\
0.26-0.47\end{array}$ & $\begin{array}{c}0.06(0.11) \\
0.04-0.08\end{array}$ & $\begin{array}{r}1.6(2.76) \\
(1.34-1.92)\end{array}$ \\
\hline
\end{tabular}

$\mathrm{IC}_{50}$ obtained by nonlinear regression from 2 independent experiments in triplicate. 
shown cytotoxicity against various cell lines with a similar profile. In general, the majority of the thionaphthoquinones had shown cytotoxic activity lower than $5 \mu \mathrm{M}$, except for compound 11, with higher cytotoxicity against normal cells than for cancer cell lines.

K562 was the most sensitive cell line, with several values of $\mathrm{IC}_{50}$ lower than $2 \mu \mathrm{M}$, reaching the lowest value of $0.9 \mu \mathrm{M}$ for compound $\mathbf{2}$, while SF-295 was the most resistant, allowing to discriminate compound $\mathbf{8}$ as the less active compound in the series. The cytotoxicity of the compounds toward SF295 was lower than $5 \mu \mathrm{M}$, except for compounds $\mathbf{8}$ and $\mathbf{1 1 .}$

When evaluating the prostate cancer cell line (PC3), $\mathrm{IC}_{50}$ values $<5 \mu \mathrm{M}$ were obtained for the majority of compounds, except for compounds 11 and 12, being compound $\mathbf{6}$, highly active. Toward the colon carcinoma HCT-116, a similar profile is observed, with $\mathrm{IC}_{50}$ values close to $2 \mu \mathrm{M}$ for $\mathbf{2}, \mathbf{3}, \mathbf{5}, \mathbf{6}, \mathbf{8}$ and $\mathbf{1 0}$.

Table 3 lists the selectivity index $(\mathrm{SI})\left(\mathrm{SI}=\mathrm{IC}_{50}{\mathrm{PBMC} / \mathrm{IC}_{50}}\right.$ cancer line) for all the quinones, concerning each cancer line. SI allows the evaluation of the selectivity of each compound toward cancer cells and could indicate the potential for further pre-clinical studies. ${ }^{54}$

Figure 9 allows a better visualization, for comparison purposes, showing the threshold of 2, as the limit to be considered significant in terms of selectivity index.

Suffness and Pezzuto ${ }^{58}$ considered SI significant for values greater than or equal to 2.0, i.e., that value means that the compound exhibits twice more activity toward the neoplastic cell line than in normal cells. SI values lower than 2.0 indicate low selectivity. Only three quinones had SI values higher than 2, being: 5, in which the SI values are 2.3 and 3.14 against K562 and HCT-116, respectively;

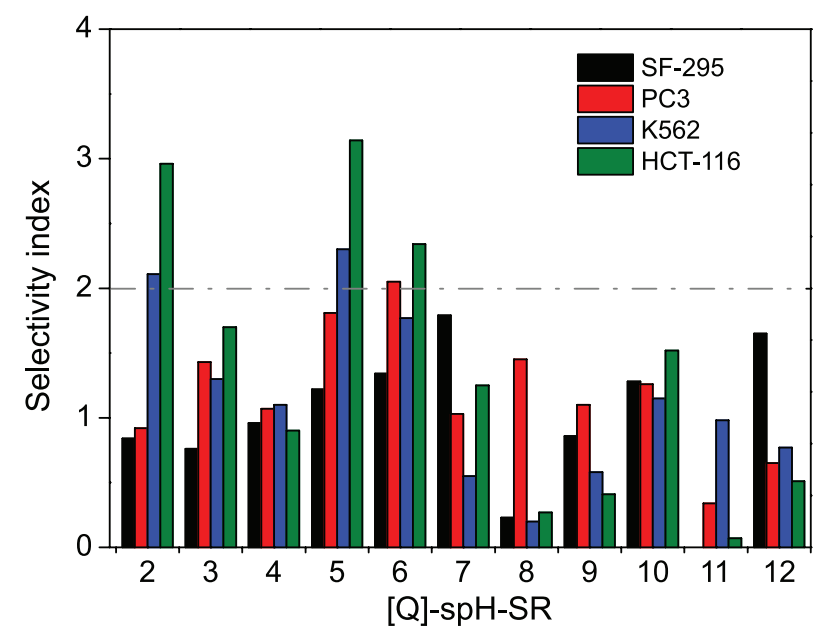

Figure 9. Graph showing selectivity indexes, for the 4 cancer cell lines studied for the 12 thionaphthoquinones, using 2 as a referenced selectivity index.

compound 2 shows an SI of 2.11 against K562 and 2.96 against HCT-116 and finally, $\mathbf{6}$, with SI of 2.34 toward HCT-116.

These differences in $\mathrm{IC}_{50}$ values are minor, yet noticeable. Still, there is no significant "selective cytotoxicity" against one particular cell line, which is somewhat disappointing yet not entirely, unexpected.

\section{Compound 2 increases intracellular ROS levels}

Generation of intracellular ROS is considered one of the key mediators of quinone's anticancer effects. Therefore, the redox status of treated HCT-116 cells was monitored using the oxidation-sensitive fluorescent dye CM- $\mathrm{H}_{2}$ DCFDA after $30 \mathrm{~min}, 1$ and $3 \mathrm{~h}$ of incubation. Compound 2 induced an increase in intracellular ROS levels in both concentrations tested. In the lower concentration

Table 3. Selectivity index $\left[\mathrm{IC}_{50}(\mathrm{PBMC}) / \mathrm{IC}_{50}\right.$ (cancer line)] for each of the four used cancer lines

\begin{tabular}{|c|c|c|c|c|}
\hline \multirow{2}{*}{ Compound } & \multicolumn{4}{|c|}{ Selectivity index $\left[\mathrm{IC}_{50}(\mathrm{PBMC}) / \mathrm{IC}_{50}\right.$ (cancer line) $]$} \\
\hline & SF 295 (glioblastoma) & PC3 (prostate) & K562 (leukemia) & HCT-116 (colon carcinoma) \\
\hline 2 & 0.84 & 0.92 & 2.11 & 2.96 \\
\hline 3 & 0.76 & 1.43 & 1.30 & 1.70 \\
\hline 4 & 0.96 & 1.07 & 1.10 & 0.90 \\
\hline 5 & 1.22 & 1.81 & 2.3 & 3.14 \\
\hline 6 & 1.34 & 2.05 & 1.77 & 2.34 \\
\hline 7 & 1.79 & 1.03 & 0.55 & 1.25 \\
\hline 8 & 0.23 & 1.45 & 0.20 & 0.27 \\
\hline 9 & 0.86 & 1.10 & 0.58 & 0.41 \\
\hline 10 & 1.28 & 1.26 & 1.15 & 1.52 \\
\hline 11 & ND & 0.34 & 0.98 & 0.07 \\
\hline 12 & 1.65 & 0.65 & 0.77 & 0.51 \\
\hline
\end{tabular}

ND: not determined. 
$(2.4 \mu \mathrm{M})$, an increase in DCF fluorescence was detected in a time-dependent manner, with the fluorescence being more intense at $3 \mathrm{~h}$. In the higher concentration $(4.8 \mu \mathrm{M})$, the DCF fluorescence was similar among the periods of time tested, being more intense in the first $30 \mathrm{~min}$ (Figure 10). As expected, menadione and hydrogen peroxide, used as positive controls, increased ROS generation in treated cells, with a peak of production at $1 \mathrm{~h}$.

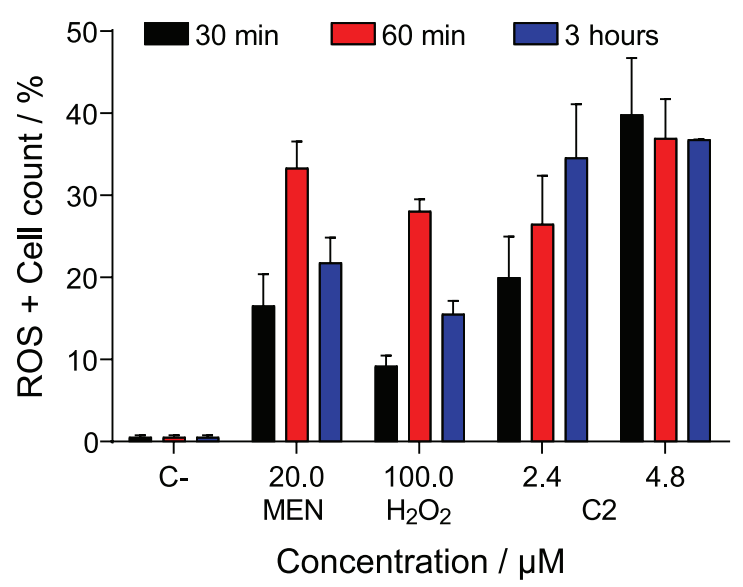

Figure 10. Effect of compound 2 (C2) on ROS production in HCT-116 cells, determined by flow cytometry using CM- $\mathrm{H}_{2}$ DCFDA, after $30 \mathrm{~min}$, 1 and $3 \mathrm{~h}$ incubation. Menadione (MEN, $20 \mu \mathrm{M}$ ) and hydrogen peroxide $\left(\mathrm{H}_{2} \mathrm{O}_{2}, 100 \mu \mathrm{M}\right)$ were used as positive controls and $\mathrm{C}$ - is the negative control (buffer alone). A total of 5,000 events were analyzed per sample. Data are expressed as mean \pm SEM from two independent experiments.

As several other clinically used quinones, compound $\mathbf{2}$ was able to increase intracellular ROS levels over a critical threshold. The high ROS content in cancer cells, due to their accelerated metabolism, renders them more susceptible to oxidative stress-induced cell death, and can be exploited for selective cancer therapy.

In the class studied, the insertion of a sulfur atom increased the polarizability, conferring an increase in lipophilicity, which suggests a change in the profile related to this aspect in relation to nor-beta-lapachone (1).

The activity of biologically active compounds is related to their physicochemical properties, since they must cross membrane barriers and reach their receptor site $(\mathrm{s})$ in order to perform their action, thus triggering the biological response. In electrochemistry, the main thermodynamic parameter of correlation with the biological activity of a specific group is the potential of the first reduction wave $\left(\mathrm{E}_{\mathrm{p}} \mathrm{I}_{\mathrm{c}}\right) .{ }^{18} \mathrm{~A}$ graph between $\mathrm{IC}_{50}$ and $\mathrm{E}_{\mathrm{p}} \mathrm{I}_{\mathrm{c}}$ of the quinones was built (Figure 11). Although the data available to date is limited, hampering a definite structure-reactivity relationship, there is some support for this notion.

Despite the absence of a linear correlation in the graph, there is a trend and an optimal range for the reduction potential. All the compounds, in aprotic medium, with

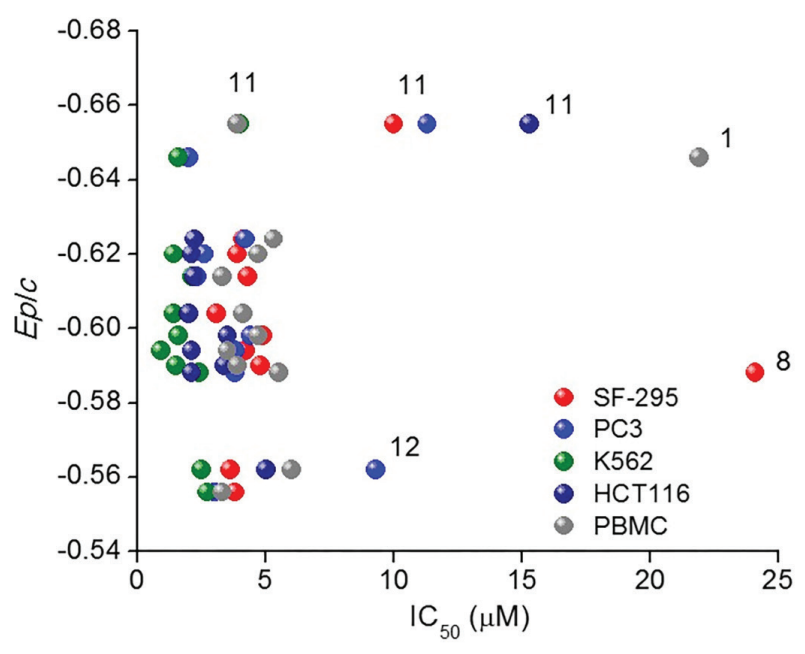

Figure 11. Relationship between $\mathrm{E}_{\mathrm{p}} \mathrm{I}_{\mathrm{c}}$ (potential of the first reduction peak), in $\mathrm{V}$, and $\mathrm{IC}_{50}(\mu \mathrm{M})$, in 4 cancer cell lines and PBMC, with colors shown inside the figure. Numbers are related to the compounds. Compounds $\mathbf{8 , 1 1}$ and 12 were less active. Compound 1 (nor-beta-lapachone), the standard, is not toxic toward PBMC.

values of first wave reduction potential $\left(\mathrm{E}_{\mathrm{p}} \mathrm{I}_{\mathrm{c}}\right)$, larger (less negative) than $-0.65 \mathrm{~V}$, were active $\left(\mathrm{IC}_{50}\right.$ lower than $5 \mu \mathrm{M}$ ). Compounds 8 and 11, referring to the SF-295 lineage, were outside this biological activity region. This trend was evidenced in some articles, ${ }^{18,19,56,57,59}$ despite the complexity of cell chemistry, redox medicine and cancer disease.

\section{Conclusions}

The electrochemical results have confirmed the presence of two distinct and independent redox couples in this series: the quinone and the thio component. In the biological perspective, agents containing chalcogens and quinones can be used to attack entities with a disturbed redox balance, while protecting healthy cells, working as antioxidants and leading to highly selective redox therapeutic agents.

The work presented here should be seen as providing the impetus for follow-on investigations, including synthetic chemistry and cell biology. These molecules are not only intriguing from a purely synthetic point of view. They also provide several interesting leads for possible drug development, which are not limited to cancer research, but also appear to include lesser exposed, yet equally important areas of pharmaceutical research, such as antimalarial and anti-fungal therapies, being a fertile ground for various multidisciplinary follow-on projects. ${ }^{60}$

These studies are, of course, only an entry point for considerably wider and more in-depth investigations, which ultimately may also consider mechanistic aspects and biochemical mode(s) of action. ${ }^{60}$ 


\section{Supplementary Information}

Supplementary data (NMR, FTIR, HRMS, cyclic voltamograms) are available free of charge at http://jbcs.sbq.org.br as a PDF file.

\section{Acknowledgments}

The authors wish to thank the Brazilian financial agencies: CNPq, CAPES, FAPEAL, FAPESP and INCT in Bioanalytics (FAPESP No. 2014/50867-3 and CNPq No. 465389/2014-7, 458114/2014-6). M. F. C. C., V. F. F. and F. C. S. thank to FAPERJ for the grants and fellowships.

\section{References}

1. Sies, H.; Berndt, C.; Jones, D. P.; Annu. Rev. Biochem. 2017, 86,715 .

2. Sies, H.; Jones, D. P. In Encyclopedia of Stress, vol. 3; Fink, G., ed.; Elsevier: Amsterdam, 2007, p. 45.

3. Valko, M.; Leibfritz, D.; Moncol, J.; Cronin, M. T. D.; Mazura, M.; Telser, J.; Int. J. Biochem. Cell Biol. 2007, 39, 44.

4. Pelicano, H.; Carney, D.; Huang, P.; Drug Resist. Updates 2004, 7,97.

5. Viswanathan, U. M.; Burkholz, T.; Jacob, C. Z.; Phys. Chem. 2013, 227, 691 .

6. Jamier, V.; Ba, L. A.; Jacob, C.; Chem. - Eur. J. 2010, 16, 10920.

7. Trachootham, D.; Alexandre, J.; Huang, P.; Nat. Rev. Drug Discovery 2009, 8, 579.

8. Cabello, C. M.; Bair, W. B.; Wondrak, G. T.; Curr. Opin. Invest. Drugs 2007, 8, 1022.

9. Wondrak, G. T.; Antioxid. Redox Signaling 2009, 11, 3013.

10. Fry, F. H.; Holme, A. L.; Giles, N. M.; Giles, G. I.; Collins, C.; Holt, K.; Pariagh, S.; Gelbrich, T.; Hursthouse, M. B.; Gutowski, N. J.; Jacob, C.; Org. Biomol. Chem. 2005, 3, 2579.

11. Giles, N. M.; Gutowski, N. J.; Giles, G. I.; Jacob, C.; FEBS Lett. 2003, 535, 179.

12. Shaaban, S.; Diestel, R.; Hinkelmann, B.; Muthukumar, Y.; Verma, R. P.; Sasse, F.; Jacob, C.; Eur. J. Med. Chem. 2012, $58,192$.

13. Doering, M.; Diesel, B.; Gruhlke, M. C. H.; Viswanathan, U. M.; Mániková, D.; Chovanec, M.; Burkholz, T.; Slusarenko, A. J.; Kiemer, A. K.; Jacob, C.; Tetrahedron 2012, 68, 10577.

14. Vieira, A. A.; Brandão, I. R.; Valença, W. O.; de Simone, C. A.; Cavalcanti, B. C.; Pessoa, C.; Carneiro, T. R.; Braga, A. L.; da Silva Jr., E. N.; Eur. J. Med. Chem. 2015, 101, 254.

15. Giles, G. I.; Tasker, K. M.; Johnson, R. J. K.; Jacob, C.; Peers, C.; Green, K. N.; Chem. Commun. 2001, 2490.

16. Giles, G. I.; Giles, N. M.; Collins, C. A.; Holt, K.; Fry, F. H.; Lowden, P. A. S.; Gutowski, N. J.; Jacob, C.; Chem. Commun. 2003, 2030.
17. Jardim, G. A. M.; da Cruz, E. H. G.; Valença, W. O.; Lima, D. J. B.; Cavalcanti, B. C.; Pessoa, C.; Rafique, J.; Braga, A. L.; Jacob, C.; da Silva Jr., E. N.; da Cruz, E. H. G.; Molecules 2018, 23,83 .

18. Hillard, E. A.; de Abreu, F. C.; Ferreira, D. C. M.; Jaouen, G.; Goulart, M. O. F.; Amatore, C.; Chem. Commun. 2008, 2612.

19. de Paiva, Y. G.; Ferreira, F. R.; Silva, T. L.; Labbé, E.; Buriez, O.; Amatore, C.; Goulart, M. O. F.; Curr. Top. Med. Chem. 2015, 15, 136.

20. Silva, T. L.; Ferreira, F. R.; Vasconcelos, C. C.; da Silva, R. C.; Lima, D. J. P.; Costa, P. R. R.; Netto, C. D.; Goulart, M. O. F.; ChemElectroChem 2016, 3, 2252.

21. Ferreira, D. C. M.; Tapsoba, I.; Arbault, S.; Bouret, Y.; Moreira, M. S. A.; Pinto, A. V.; Goulart, M. O. F.; Amatore, C.; ChemBioChem 2009, 10, 528.

22. da Silva Jr., E. N.; Souza, M. C. B. V.; Fernandes, M. C.; MennaBarreto, R. F. S.; Pinto, M. C. F. R.; Lopes, F. A.; Simone, C. A.; Andrade, C. K. Z.; Pinto, A. V.; Ferreira, V. F.; Castro, S. L.; Bioorg. Med. Chem. 2008, 16, 5030.

23. Cardoso, M. F. C.; da Silva, I. M. C. B.; dos Santos Jr., H. M.; Rocha, D. R.; Araújo, A. J.; Pessoa, C.; de Moraes, M. O.; Lotufo, L. V. C.; da Silva, F. C.; Santos, W. C.; Ferreira, V. F.; J. Braz. Chem. Soc. 2013, 24, 12.

24. Jacob, C.; Giles, G. I.; Giles, N. M.; Sies, H.; Angew. Chem., Int. Ed. 2003, 42, 4742.

25. da Cruz, E. H. G.; Silvers, M. A.; Jardim, G. A. M.; Resende, J. M.; Cavalcanti, B. C.; Bomfim, I. S.; Pessoa, C.; de Simone, C. A.; Botteselle, G. V.; Braga, A. L.; Nair, D. K.; Namboothiri, I. N. N.; Boothman, D. A.; da Silva Jr., E. N.; Eur. J. Med. Chem. 2016, 122,1 .

26. Guimarães, E.; Hussene, C.; Dias, G. G.; Diogo, E. B. T.; de Melo, I. M. M.; Rodrigues, B. L.; Valença, W. O.; Camara, C. A.; da Silva, M. G.; de Oliveira, R. N.; de Paiva, Y. G.; Goulart, M. O. F.; Cavalcanti, B. C.; Pessoa, C.; da Silva Jr., E. N.; Bioorg. Med. Chem. 2014, 22, 1608.

27. Bhasin, D.; Chettiar, S. N.; Etter, J. P.; Mok, M.; Li, P. K.; Bioorg. Med. Chem. 2013, 21, 4662.

28. Sharma, A.; Santos, I. O.; Gaur, P.; Ferreira, V. F.; Garcia, C. R. S.; da Rocha, D. R.; Eur. J. Med. Chem. 2013, 59, 48.

29. da Silva, F. C.; Ferreira, V. F.; Curr. Org. Synth. 2016, 13, 334.

30. Ibis, C.; Ayla, S. S.; Yavuz, S.; Phosphorus, Sulfur Silicon Relat. Elem. 2014, 189, 492.

31. Ibis, C.; Ayla, S. S.; Asar, H.; Synth. Commun. 2014, 44, 121.

32. Ibis, C.; Shntaif, A. H.; Bahar, H.; Ayla, S. S.; J. Serb. Chem. Soc. 2015, 80, 731

33. Walsh, J. S.; Miwa, G. T.; Annu. Rev. Pharmacol. Toxicol. 2011, 51,145 .

34. Ferreira, F. R.; Ferreira, S. B.; Araújo, A. J.; Marinho Filho, J. D. B.; Pessoa, C.; Moraes, M. O.; Costa-Lotufo, L. V.; Montenegro, R. C.; Silva, F. C.; Ferreira, V. F.; da Costa, J. G.; 
de Abreu, F. C.; Goulart, M. O. F.; Electrochim. Acta 2013, 110, 634.

35. de Abreu, F. C.; Ferraz, P. A. L.; Goulart, M. O. F.; J. Braz. Chem. Soc. 2002, 13, 19.

36. Goulart, M. O. F.; Ossowski, T.; Pipka, P.; Liwo, A.; Bioelectrochemistry 2003, 59, 85.

37. Goulart, M. O. F.; Lima, N. M. F.; Santana, A. E. G.; Ferraz, P. A. L.; Cavalcanti, J. C. M.; Liwo, A.; Falkowsky, P.; Ossowsky, T.; J. Electroanal. Chem. 2004, 566, 25.

38. Bard, A. J.; Faulkner, L. R.; Electrochemical Methods: Fundamentals and Applications; Wiley: New York, 2001.

39. Mosmann, T.; J. Immunol. Methods 1983, 65, 55.

40. Hamid, R.; Rotshteyn, Y.; Rabadi, L.; Parikh, R.; Bullock, P.; Toxicol. In Vitro 2004, 18, 703.

41. GraphPad Prism 5.0; GraphPad Software Inc., San Diego, USA, 2007.

42. LeBel, C. P.; Ischiropoulos, H.; Bondy, S. C.; Chem. Res. Toxicol. 1992, 5, 227.

43. Lehmann, M. W.; Evans, D. H.; J. Electroanal. Chem. 2001, $500,12$.

44. Meneses, A. B.; Antonello, S.; Arevalo, M. C.; Maran, F.; Electrochim. Acta 2005, 50, 1207.

45. Meneses, A. B.; Antonello, S.; Arvalo, M. C.; Gonzalez, C. C.; Sharma, J.; Wallette, A. N.; Workentin, M. S.; Maran, F.; Chem. - Eur. J. 2007, 13, 7983.

46. Viertler, H.; Gruber, J.; Pardini, V. L. In Organic Electrochemistry; Lund, H.; Hammerich, O., eds.; Marcel Dekker Inc.: New York, 2001, p. 621 (and included references).

47. Dakova, B.; Lambews, I.; Evers, M.; Electrochim. Acta 1994, 39, 2363.

48. Baciocchi, E.; Rol, C.; Scamosci, E.; Sebastiani, G. V.; J. Org. Chem. 1991, 56, 5498.

49. France, R. R.; Rees, N. V.; Wadhawan, J. D.; Fairbanks, A. J.; Compton, R. G.; Org. Biomol. Chem. 2004, 2, 2188.
50. Sawyer, D. T.; Velentine, J. S.; Acc. Chem. Res. 1981, 14, 393.

51. Vasudevan, D.; Wendt, H.; J. Electroanal. Chem. 1995, 192, 69.

52. Antunes, F.; Salvador, A.; Marinho, H. S.; Alves, R.; Pinto, R. E.; Free Radical Biol. Med. 1996, 21, 917.

53. Song, Y.; Buettner, G. R.; Free Radical Biol. Med. 2010, 49, 919.

54. Perez-Sacau, E.; Diaz-Peñate, R. G.; Estevez-Baun, A.; Ravelo, A. G.; Garcia-Castellano, J. M.; Pardo, L.; Campillo, M.; J. Med. Chem. 2007, 50, 696.

55. da Silva Jr., E. N.; de Deus, C. F.; Cavalcanti, B. C.; Pessoa, C.; Costa-Lotufo, L. V.; Montenegro, R. C.; Moraes, M. O.; Pinto, M. C. F. R.; Simone, C. A.; Ferreira, V. F.; Goulart, M. O. F.; Andrade, C. K. Z.; Pinto, A. V.; J. Med. Chem. 2010, 53, 504.

56. da Silva Jr., E. N.; de Souza, M. C. B. V.; Pinto, A. V.; Pinto, M. C. F. R.; Goulart, M. O. F.; Barros, F. W. A.; Pessoa, C.; Costa-Lotufo, L. V.; Montenegro, R. C.; de Moraes, M. O.; Ferreira, V. F.; Bioorg. Med. Chem. 2007, 15, 7035.

57. Cavalcanti, B. C.; Barros, F. W. A.; Cabral, I. O.; Ferreira, J. R. O.; Magalhães, H. I. F.; Júnior, H. V. N.; da Silva Júnior, E. N.; de Abreu, F. C.; Costa, C. O.; Goulart, M. O. F.; Moraes, M. O.; Pessoa, C.; Chem. Res. Toxicol. 2011, 24, 1560.

58. Suffness, M.; Pezzuto, J. M. In Methods in Plant Biochemistry: Assays for Bioactivity, vol. 6; Hostettmann, K., ed.; Academic Press: London, 1990, p. 71.

59. Koyama, J.; Morita, I.; Yamori, T.; Molecules 2010, 15, 6559. 60. Mecklenburg, S.; Shaaban, S.; Ba, L. A.; Burkholz, T.; Schneider, T.; Diesel, B.; Kiemer, A. K.; Röseler, A.; Becker, K.; Reichrath, J.; Stark, A.; Tilgen, W.; Abbas, M.; Wessjohann, L. A.; Sasse, F.; Jacob, C.; Org. Biomol. Chem. 2009, 7, 4753.

Submitted: August 11, 2018 Published online: December 18, 2018 